\title{
Is Life More Risky in the Open? Household Risk-Coping and the Opening of China's Labor Markets
}

\author{
By: John Giles
}

Working Paper Number 314

April 2000 


\title{
Is Life More Risky in the Open? Household Risk-Coping and the Opening of China's Labor Markets
}

\author{
John Giles* \\ Michigan State University
}

April 14, 2000

\begin{abstract}
This paper looks at the effect of access to off-farm employment opportunities on household exposure to unexpected shocks originating in the agricultural economy. Farm households with improved access to both migrant and local labor markets are better able to cope with shocks to agricultural production. The risk-coping benefits of improved access to off-farm markets are not shared evenly within or across villages. Wealthier households show a more pronounced reduction in exposure to shocks, including less variable income and consumption, and a reduced impact of production shocks on expenditures related to the education of children.
\end{abstract}

\footnotetext{
${ }^{*}$ Assistant Professor, Department of Economics, Michigan State University. Contact Information: 101 Marshall Hall, Michigan State University, East Lansing, MI, 48824 (gilesj@msu.edu). I gratefully thank Liqun Cao and Xiaohui Zhang of the Survey Department of the Research Center on the Rural Economy (RCRE) at the Ministry of Agriculture in Beijing for making RCRE's household and village survey data available for this research, and for their assistance in arranging follow up interviews and surveys in sampled villages. Much thanks to Pranab Bardhan, Paul Gertler, Albert Park, Scott Rozelle, John Strauss, and Yongmei Zhou for many helpful comments. I am solely responsible for all deficiencies.
} 


\section{Introduction}

Households in rural areas of developing countries often struggle with both poverty and low incomes that vary sharply with shocks to agricultural production. Recent research in economic development has looked at how well such households insure consumption in the face of shocks (Townsend, 1994, 1995; Chaudhuri and Ravallion, 1997), and implications for household resource allocation of ex ante risk-management behavior (Morduch, 1992, 1995). Further research on the mechanisms used to reduce the impact of shocks has detailed the importance of such ex post mechanisms as credit market transactions (Udry, 1994), depletion of household savings (Paxson, 1992; Udry, 1995; Alderman, 1996), expanded participation in off-farm activities (Kochar, 1999), and transfers from family members who have migrated out of the community (Rosenzweig and Stark, 1989; Paulson, 1994).

For the most part, research on exposure to shocks and coping mechanisms has concentrated on the experience of relatively static rural economies. ${ }^{1}$ For those regions of the developing world also undergoing economic transition, there are further important questions regarding the effect of access to markets on both exposure to agricultural production shocks, and on the salience of traditional mechanisms used to insure consumption. The rural Chinese economy provides an interesting and dynamic environment for the study of these issues. $^{2}$ Over the last fifteen years, some regions of rural China have witnessed extraordinarily rapid, if uneven, growth of access to labor markets in both urban and rural areas. The growth of these markets provides both a new source of income and a means of reducing exposure to shocks affecting agricultural production. At the same time, however, it is likely that households differ in the ease with which they shift labor between sectors and, consequently, in their ability to benefit from these off-farm labor markets.

This paper looks at the impact of off-farm labor markets on exposure to shocks affecting agricultural income. The gradual and uneven transition to greater labor market access

\footnotetext{
${ }^{1}$ An exeption is Jalan and Ravallion's (1999) research using an earlier panel of data from rural China. The data used in their research lacked the detailed community level data present in the RCRE dataset used in this analyses, and also ended in 1990. For this reason, it predated the rapid expansion of markets for migrant labor that ocurred between 1991 and 1997.

${ }^{2}$ This paper focuses on the exposure question, and another focuses on changes in risk-coping mechanisms.
} 
across rural China provides a unique quasi-natural experiment. By making use of a twelveyear panel of village and household data, this paper shows that access to markets reduces household exposure to unexpected shocks affecting agricultural production. At the same time, however, the risk-coping benefits provided by access to off-farm labor markets are not shared evenly within or across communities. As villages become more connected to wage labor markets, wealthier households show a more pronounced reduction in exposure to shocks affecting both income and consumption.

One important challenge faced by this paper is the likelihood that levels of participation in off-farm labor markets are correlated with observed shocks to the local economy. Where exogenous geographic variables recommend themselves as useful measures of physical closeness to markets, evidence from research on migration in China suggests that history of prior migration from a village may be more important than geography in providing access to information about opportunities for off-farm employment (Meng, 1996; Rozelle et al, 1999). Using variables from a separate village level survey and community information on rainfall, this paper controls for possible endogeneity of decisions to participate in off-farm markets and shows that access to these markets offers a means of reducing income and consumption variability.

In addition, the paper recognizes the likelihood that labor markets may function differently depending on the ownership structures and employment practices of local enterprises. If access to employment in collective enterprises requires favorable recommendation from village leaders (Chen, 1997), employment in collectives may be rationed, thus making it more difficult to find work in these enterprises subsequent to a shock. Private enterprises, on the other hand, may hire fewer village residents for political purposes, but they will also find it easier to dismiss employees in the event of downturns affecting the local economy. Village surveys used in the analyses allow us to separately distinguish between changes in access to collective and private employment, and changing opportunities for employment as temporary migrants outside the village.

The paper first offers a brief discussion of the types of non-agricultural employment open to rural households in Section 2. Section 3 builds on an approach introduced by Paxson 
(1992) that identifies the effect of rainfall shocks on income, and then uses measures of market access to determine the impact of off-farm employment opportunities on exposure to these shocks. Next, Section 4 shows that as villages become more connected to local and distant markets for wage labor, households are better able to reduce the effect of rainfall shocks on consumption of non-durable goods. Of particular importance for the accumulation of human capital, this section also provides evidence that expenditures related to education of children are less responsive to agricultural production shocks as access to local off-farm labor markets improves. A final section concludes with a discussion of the relevance of these findings for current policy discussions regarding the mobility of rural labor in China.

\section{Growth of Markets for Rural Labor}

Economic reform in post-Mao China started with the decollectivization of agriculture after 1978. A one shot gain to efficiency was realized as decisions regarding management of farm production were devolved to households under the Household Responsibility System (HRS). Improved incentives for farm households led to the expansion of farm output and incomes that occurred during the early and mid-1980s (Macmillan, Whalley and Zhu, 1989; Lin 1992). After realization of gains from more efficient farming in the 1980s, however, institutional barriers to efficient trade in factors of production continued to hinder the efficient utilization of resources in rural China. Obstacles to the transfer of land, the continued rationing of credit, and restrictions on the movement of labor have all been held responsible for the stagnation of incomes in some parts of rural China (Putterman, 1993).

During the 1990s, growth in markets for off-farm labor appears to have eased inefficiency in labor allocation and facilitated renewed growth of rural incomes (Benjamin and Brandt, 1999). The twelve-year panel of household and village data used in this chapter captures the heterogeneity in both the pace and forms of labor market growth, and lends itself to an analysis of how dramatic changes in off-farm opportunities affect the well-being of rural farm households. Two features of this panel are quite striking. First, opportunities for local off-farm employment remain unevenly distributed across this sample of villages, yet 
roughly half the villages show a significant increase in the number of residents employed in "private sector" jobs during the 1990s. Not surprisingly, those villages near large cities or in the coastal province of Jiangsu show far greater levels of local off-farm employment than more remote villages. Second, the panel picks up the rapid growth of China's population of rural migrants after 1991. In the 1990s, opportunities for migrant employment brought the benefits of off-farm employment to households in regions of China which had previously been quite remote.

\subsection{Components of Off-Farm Employment}

The off-farm labor market is comprised of markets for local wage labor, markets for migrant labor, and self-employed off-farm activities of households. Because these different components of the labor market have not developed at an even pace across different regions of rural China, the impact of the growth of each of these markets is considered separately.

The decision to participate in migrant or local off-farm labor markets depends on a range of factors reflecting both the health of local economies, information flows between villages and distant labor markets, wage differentials, riskiness of employment, and household ability and decision to participate in each type of market. In order to get a picture of the scale of off-farm employment across the 44 villages under study, measures of access to off-farm wage employment are first constructed from village level survey data. In the community survey, village leaders and accountants were asked how many legal residents were employed at some time during the year in local enterprises of a variety of ownership types. In addition, they were also asked to estimate the number of legal residents employed in migrant activities at different distances from the village during the year. While these numbers are necessarily rough estimates, they provide some measure of connection to different labor markets. Measures of access to each type of labor market are defined as the share of legal village residents estimated to be in each employment category: local collective enterprise employment, local private enterprises, and migrant employment. ${ }^{3}$ Figures 1-3 present

\footnotetext{
${ }^{3}$ Ideally one might also wish to consider self-employment in non-agricultural activities as another category. Before 1993, unemployed (or underemployed) labor appears to be confounded with self-employed activities
} 
summaries of the distributions of these measures over time.

Two significant developments are picked up by the village level measures of labor market access. First, Figure 1 captures the dramatic jump in migrant employment with the rapid growth of China's "floating population" after 1991. Various estimates place the size of this migrant labor force at between 60 and 100 million rural laborers in 1995 - making this one of the largest scale movements of labor in human history. Second, Figure 2 shows the expansion of private wage employment opportunities during the 1990s, ${ }^{4}$ and Figure 3 shows milder increases in the share of labor with some collective enterprise employment.

\section{$2.2 \quad$ Local Off-Farm Labor Markets}

Before the loosening of the residential registration system in the early '90s, off-farm nonagricultural labor markets were a localized phenomena that first developed in pockets near the coast or in the outskirts of large cities - regions that inherited the assets of Maoist brigade enterprises and located in areas in which they had some chance of operating profitably (Putterman, 1993). Access to these off-farm labor markets was thus rationed by the geographic location of the household's residential registration.

During the mid and late 1980s, these Township and Village Enterprises (TVEs) became one of the booming sectors of the Chinese economy and brought substantial increases in the incomes of rural residents who could find employment in them. Disparities in wealth grew across regions as income growth lagged in localities where enterprises could not develop profitably (Rozelle and Jiang, 1994; Morduch and Sicular, 1996).

Research on the use of local labor markets to smooth shocks in rural India has shown that households expand days of local employment to smooth shocks experienced on farm (Kochar, 1996). In some regions of China, the prospect that households can use local employment to smooth shocks is limited by the dearth of local off-farm employment opportunities in many areas. In addition, where off-farm local employment is concentrated in collective enterprises, there is more likelihood that access to a job requires connections and may not in the village level survey.

${ }^{4}$ Following the literature on rural enterprises, I consider private sector employment to include laborers employed in both private firms and collectively-owned firms with assets contracted out to managers. 
be a convenient source of casual employment. Ability to expand local employment in the face of shocks, then, may not be open to all households. In the villages of Jiangsu and the Hefei suburbs (of Anhui), opportunities for employment in private enterprises are fairly abundant by the mid-1990s. Increased access to wage jobs in private firms appears to be more beneficial for smoothing unexpected production shocks, suggesting that markets may be better functioning in those areas with more private wage opportunities.

\subsection{Migrant Labor Markets}

As a result of institutional rigidities of the residential registration system, poor information about jobs, and uncertainty over consequences of hiring migrants illegally, flows of migrant labor grew only slowly during the 1980s. As of the late '80s, most rural migrants operated stalls selling vegetables in markets, worked as employees or owners of road-side small restaurants, repair shops, or other informal sector activities in urban areas, or were engaged in rural to rural migration facilitated through kinship ties (Mallee, 1996). Growing demand for construction and service sector workers during the booming years of the '90s, however, fueled demand for laborers interested in jobs that were unattractive to urban workers. City governments introduced work permits allowing migrants temporary employment in a range of construction, service, and industrial job categories (Wang and Zuo, 1999). Contacts between earlier migrants and rural communities then facilitated expansion of both formal and informal ties between enterprises in destination communities and potential migrants in source communities (Meng, 1996).

In the last few years, a significant body of research conducted by both Western and Chinese scholars has focussed on identifying the determinants of migration in China. In studies focussing on characteristics of migrants and source communities, researchers have alternatively attributed migration ability to level of education, household demographic composition, and level of household wealth. ${ }^{5}$ A recent six-province survey of village leaders

\footnotetext{
${ }^{5}$ Alternative and sometimes contradictory explanations of the determinants of migration can be found in Solinger (1996), Mallee (1996), Yang and Zhou (1996), Meng (1996), Hare and Zhao (1996), and Parrish, Zhe and Li (1995).
} 
suggests two aspects of migration in China consistent with rural to urban migration experiences else where in the developing world - the poorest households are often not capable of participating in migrant labor markets, and information flows regarding opportunities are most important in determining which villages will have high levels of out-migration (Rozelle et al, 1998).

The temporary or "rotational" nature of China's migrant labor force is also evident both in Rozelle et al (1998) and in the RCRE panel used in this study. In common with the experience of other developing countries, it is rare for entire households to migrate. Instead, members of families will work outside the village as temporary migrants, and return at different times of the year to assist with the harvest or other economic activities of the household. Explanations of this migration pattern point to both the difficulty of obtaining permanent legal residence in urban areas (Yang, 1997), and the unclear property rights over the land allocated to the family in the village (Benjamin and Brandt, 1999). If an entire family leaves a village for a long period of time, it may well find its land reallocated to other households in the village. Given that access to land in rural China plays an important role as a safety net guaranteeing households a means of earning an income, few households are willing to forfeit this source of security unless their off-farm employment can be viewed as permanent. ${ }^{6}$

For most households in villages of the RCRE survey, then, migrant wage employment offers one of many potential income earning activities to diversified households. ${ }^{7}$ Empirical research using survey data from other regions of the developing world has detailed the riskcoping benefits of migrant employment opportunities (Paulson, 1996). Given the rapid growth in the volume of trans-regional migrants in China, it is somewhat surprising that no significant research has analyzed the impact of migration on risk-coping behavior in source villages. The twelve-year panel of data used in this study offers a unique chance to study

\footnotetext{
${ }^{6}$ Another paper using the same sample from the RCRE dataset shows that the off-farm migration decision is affected by behavioral responses to risk, realized shocks, and the strength of control rights over land (Giles, 2000).

${ }^{7}$ For the poorest wealth tercile of households in the RCRE dataset, increased access to migrant opportunity clearly contributes to the growth of household income per laborer (see the results in Table 4).
} 
the impact of rotational migration on both the exposure and risk-coping ability of migrant and non-migrant households.

Greater village levels of participation in migrant labor markets could have positive or negative effects on households without migrant employment. If, as suggested by Townsend (1994), households in a closed village economy offer each other informal insurance against shocks to income, then opening to labor markets outside the village could have a positive or negative impact on the scope for "insurance contracts" between households. To the extent that migrant income is uncorrelated with income earned locally, an increase in income earned outside the village may expand the scope for mutually beneficial co-insurance arrangements between households. At the same time, however, models of mutual insurance typically assume that households have close to perfect information about the shocks they each experience, their income realizations, and the level of effort each household puts into earning its income (Ravallion and Coate, 1993). As households start earning more income outside of villages, the information requirements necessary for mutual insurance to work become less plausible over time. In addition, households with higher savings from off-farm employment may find it more efficient to self-insure rather than rely on uncertain insurance from other members of the village. For these reasons, it is conceivable that households with migrants will be less inclined to enter into informal insurance arrangements with other households in the village, and as a result, expanded village connection to off-farm labor markets will offer few risk-coping benefits to non-participating households. The analyses of Section 4 suggest that increased village access to migrant employment facilitates the consumption smoothing. This benefit is stronger and most significant for households in the high and middle wealth terciles, though this is not surprising because less affluent households appear to leave themselves less exposed to potential swings in income. Poorer households benefit more in terms of higher incomes (Table 4) with increased migrant opportunities, but they do not appear to use the wider market as a means of reducing the idiosyncratic effects of weather shocks. 


\section{Household Income Variability and Off-Farm Employment Opportunities}

Recent research in the empirical development literature suggests that, in addition to higher earnings, off-farm employment benefits households by providing a source of income uncorrelated with income from on-farm agricultural production (Kochar, 1999; Paulson, 1996). If either migrant or local off-farm employment provides rural Chinese households a way of smoothing shocks to agricultural production, then households with improved access to off-farm employment should have less variable income. The analyses below first introduces the RCRE dataset and then shows the importance of labor market access for the growth of household incomes. The next section then discusses the empirical model used to identify the effect of increased market access on the variability of incomes. A third section discusses results.

\subsection{The RCRE Dataset}

The analyses of household incomes and consumption presented in the paper use village and household survey data provided by the Survey Department of the Research Centre on the Rural Economy (RCRE) at the Ministry of Agriculture in Beijing. Annual village surveys from 44 villages of Shanxi, Jiangsu, Anhui and Henan Provinces are used in conjunction with a panel of data spanning the period 1986 to 1997 from roughly 3100 households. $^{8}$ Economic data collected from village accountants and aggregated at the village level includes information on village finances, crops grown by households in the village, allocation of land,

\footnotetext{
${ }^{8} \mathrm{RCRE}$ has collected data from a panel of households since 1986, the survey was not conducted in 1992 and 1994 due to funding difficulties. Households are asked a range of questions regarding income from onfarm activities and off-farm employment, household consumption, land use, asset ownership, savings, formal and informal access to and provision of credit, and transfers from both village members and friends and family outside the village. Values of non-marketed grain that show up in income, consumption and grain balance sections of the survey are adjusted to reflect market prices following a procedure outlined in Chen and Ravallion (1996). The household survey is monitored by county agricultural research offices that collect expenditure, income and labor allocation information from households on a monthly basis. A staff person from the office works with households to clear up inconsistencies in the survey.
} 
and employment of village labor in enterprises of a range of management and ownership types. Tables 1 and 2 briefly summarize basic information on the surveyed villages and households.

In addition to the RCRE data, enumerators collected twenty years of monthly rainfall data from weather stations near each village in order to characterize purely exogenous shocks to the local agricultural economy. An eight-month rainfall shock was calculated as the difference between realized and expected rainfall. ${ }^{9}$ (A detailed discussion of the rainfall shock calculation is provided in an Appendix.) Table 4 presents results of a regression showing the impact of rainfall shocks on changes in household income per laborer. For these villages in this region of China, positive shocks to rainfall are correlated with shortfalls in income. ${ }^{10}$

\section{Household Demographics and Land Endowment}

The household demographic variables used include the numbers of prime age male and female laborers legally registered as living in the household and the number of dependents who are legal residents (all are subcategories of noncun changzhu renkou). Changes in numbers of laborers or dependents reflect legal changes in the household due to birth, death, marriage out of the household, splitting of the family, or legal transfer of residence. Changing legal residence is usually a long-term bureaucratic process, and not something that households are likely to engage in subsequent to a short-term shock. These variables include long-term temporary migrants out of the village as current members of the household. For these reasons, the household demographic variables reflect the family members belonging to the household over the long-term, and do not vary in response to shocks affecting the

\footnotetext{
${ }^{9}$ In calculating expected rainfall before a planting the current season's crops, it was assumed that farmers may recognize a dry year or a wet year by the start of the season. The expected rainfall for the period between March and October is calculated using twenty years of monthly rainfall data. It allows for the possibility that households recognize a dry year by March, and for correlation of rainfall accross years.

${ }^{10}$ Research in using rainfall data in Thailand (Paxson, 1992) and India (Jacobi and Skoufias, 1997), have found that shocks to rainfall in these areas are positively related with shocks to income. The villages of this study all have fairly well-developed irrigation systems. In this environment positive rainfall shocks are problematic.
} 
household or village.

\section{Measures of Human Capital}

Individual level information regarding years of schooling for each laborer is not available for the household, but the survey did record the numbers of household laborers with each of four levels of educational attainment: illiterate, elementary education, lower middle school education and upper middle school education. To these categories, a question was also asked regarding the number of household members with a "special skill." Shares of long-term family members who have attaining each education level, and with "special skill" are used to capture the human capital endowment of the household. Summaries of these variables for households of different wealth terciles are shown in Table 3. 


\section{Household Earned Income Per Laborer}

The household income variable shown in Tables 1 and 2 is the earned income per legal prime age laborer. This measure includes the value of net profits from household managed activities (including any private, non-agricultural enterprise operated by the household), wage income earned from employment in local enterprises, and net income brought back to the household by temporary migrants employed outside the home village for part of the year. The value on non-marketed grain produced by the household is valued at local market prices. All unearned net transfers, including the value of gifts to or from friends and family, are left out of this measure.

\section{Household Wealth}

In the analyses of incomes in this section and consumption in the next, the sample is split into terciles based on the lagged value of household wealth per capita. Household wealth is the sum of the value of household dwellings, production assets (including drought animals, farm implements, machinery and motorized vehicles), household bank savings, cash on hand and the net value of loans to individuals outside the household. Inclusion of net loans assumes that households could call for repayment or assistance if they were in trouble, and so these loans have value as an investment. One may also argue that only liquid wealth should be considered because only this wealth is potentially important for smoothing shocks. The results of the analyses were unchanged when the value of housing stock and illiquid production assets were left out of the wealth calculation.

\section{Determinants of Income}

In order to first get a sense of how well these demographic, human capital and market access variables reflect the likely income earned by the household, Table 4 presents results of regressions showing the relationship between income growth, increased access to off-farm opportunities, and rainfall shocks. Differences in the log of household income per laborer is regressed on the differences in household demographic, land and human capital profiles, and time-varying village measures of access to off-farm labor markets, and differences in 
rainfall shocks. Village dummy variables and province-year dummy variables are included to control for village fixed effects and growth of the provincial macroeconomy. Coefficients on the measures of human capital show that income does indeed increase as a greater share of household labor reaches higher education levels. The negative coefficient on the number of male and female laborers reflects the diminishing returns that set in as more family members work the same set of plots. The positive coefficients on measures of labor market access show that greater village participation in off-farm labor markets is indeed associated with higher incomes in the village.

Looking at the effect of increasing market access across wealth terciles, it is immediately obvious that village measures of off-farm employment reflect endogenous decisions within the village. Wealthier households show a drop in income with increased access to migrant and collective employment. This suggests that expanded participation in these labor markets is driven in part by the negative shocks affecting source communities. In addition, it is also likely that the negative sign on collective employment is picking up the inverse relationship between employment in private and collectively owned firms. As collective firms privatized in the '90s, labor employed in these firms essentially switches categories. The association of growing access to private wage employment with income growth for more affluent households appears both strong and significant.

In contrast, poorer households show an increase in income with greater access to both collective and migrant wage employment. The result for collective employment reflects a development strategy pursued by many villages in the late ' 80 s and early ' 90 s in which village leaders borrowed money to set up local collective enterprises that would then hopefully raise wages and revenues for the locality. In the wake of the credit crunch that hit China in the early '90s, many collectively owned enterprises either went bankrupt or "privatized" as firm management responsibilities were contracted out to private managers (Chen, 1997).

As evident in Table 4, the strong likelihood that changes in off-farm market participation are partially driven by community level shocks requires that we must control for these shocks in order to identify the impact of market access on variability of income and consumption. For this reason, the empirical strategy discussed below first identifies an idiosyncratic effect 
of aggregate rainfall shocks while controlling for village-wide shock and measurement error. Next it looks at the effect of market access on how well households smooth the idiosyncratic component of the shock on income.

\subsection{Empirical Estimation of the Impact of Labor Market Development on Shocks to Income}

\subsubsection{The Base Model}

Households are assumed to earn profits from agricultural production and any other household activities, $\pi_{i j t}$, and from labor income, $w_{i j t} l_{i j t}$, where $w_{i j t}$ is the local wage rate and $l_{i j t}$ is household labor supplied to wage earning activities. ${ }^{11}$ Combining income from both on-farm and off-farm activities, the income of household $i$ from village $j$ in period $t$ will be a function of household human capital, $\mathbf{h}_{i j t}$, demographic characteristics of the household, $\mathbf{z}_{i j t}$, farm size, $q_{i j t}$, and the characteristics of the village and the local economy, $\mathbf{r}_{j t}$.

$$
y_{i j t}\left(\mathbf{h}_{i j t}, \mathbf{z}_{i j t}, q_{i j t}, \mathbf{r}_{j t}\right)=\pi_{i j t}\left(\mathbf{h}_{i j t}, \mathbf{z}_{i j t}, q_{i j t}, \mathbf{r}_{j t}\right)+w_{i j t}\left(\mathbf{h}_{i j t}, \mathbf{r}_{j t}\right) l_{i j t}
$$

Note that the wage income earned by household members will depend on household specific human capital endowments and village characteristics. In order to avoid the selection issues involved in the household's complex choice from a range of off-farm activities, the analysis below simply looks at the effect of labor market access on the variability of household income. ${ }^{12}$

Starting from an approach introduced by Paxson (1992), income can be decomposed into permanent and transitory components, $y^{P}$ and $y^{T}$, and an unexplained component, $y^{E}$.

$$
y_{i j t}=y^{P}\left(\mathbf{h}_{i j t}, \mathbf{z}_{i j t}, q_{i j t}, \mathbf{r}_{j t}\right)+y^{T}\left(s_{j t}, \delta_{j t}, q_{i j t} \cdot s_{j t}\right)+y^{E}
$$

\footnotetext{
${ }^{11}$ Labor supplied off-farm will be less than the households total labor endowment, $\bar{L}_{i j t} \geq l_{i j t}$, where the labor endowment, $\bar{L}_{i j t}$, is a function of the household demographic characteristics, $z_{i j t}$.

${ }^{12}$ Input costs are not itemized and recorded separately in the RCRE dataset. It is assumed that prices of seed, fertilizer and other inputs are constant within villages, and the effect of these prices is then picked up by village·year dummy variables.
} 
Permanent income is a function of household human capital $\left(\mathbf{h}_{i j t}\right)$, demographic $\left(\mathbf{z}_{i j t}\right)$ and land characteristics $\left(q_{i j t}\right)$ of the household, and also time-varying local village effects. In reduced form, permanent income can be represented as

$$
y_{i j t}^{P}=\boldsymbol{\beta}_{1}^{\prime} \mathbf{h}_{i j t}+\boldsymbol{\beta}_{2}^{\prime} \mathbf{z}_{i j t}+\beta_{3} q_{i j t}+\mathbf{g}_{j t}+u_{i j}+\epsilon_{i j t}^{P}
$$

where $\mathbf{g}_{j t}$ are a set of village-time dummy variables picking up time-varying unobserved village characteristics that affect the household's permanent income. These include such factors as the village location and unmeasured factors as new roads and telecommunications infrastructure, and unmeasured permanent changes in the local economy. Given that only general information is available regarding the age structure of the household, it is also likely that unobserved factors affecting permanent income, $u_{i j}$, should be particularly worrisome and must be explicitly considered. Finally, we allow for a serially uncorrelated shock to permanent income, $\epsilon_{i j t}^{P}$.

Transitory income, $y_{i j t}^{T}$, is represented as a function of rainfall shocks affecting the entire village $\left(s_{j t}\right)$, other economic shocks affecting the villages $\left(\mathbf{d}_{j \times t}\right)$, and unidentified shocks affecting individual households, $\epsilon_{i j t}^{T}$. The dummy variables picking up all villagewide shocks will be perfectly collinear with the rainfall shocks, so that the aggregate effect of rainfall shocks will not be independently identifiable. Assuming that households differ in their exposure to aggregate shocks, however, an idiosyncratic effect of rainfall shocks can be identified using interactions of household land area, $q_{i j t}$, and the shock, $s_{j t}$.

$$
y_{i j t}^{T}=\boldsymbol{\alpha}_{1}\left(q_{i j t} \cdot s_{j t}\right)+\mathbf{d}_{j \times t}+\epsilon_{i j t}^{T}
$$

Jacobi and Skoufias (1998) follow a similar procedure and use lagged farm characteristics interacted with rainfall shocks. In this dataset, current household land holding is not likely to vary with the rainfall shock for two reasons. First, rental or sale transactions in rural China are still uncommon. Second, the household farm size measure in the RCRE data reflect longer-term contractual rights over the land, and do not vary systematically with annual rainfall shocks. ${ }^{13}$

\footnotetext{
${ }^{13}$ The variable used - the area of land under the household's management (jiating jingying gengdi mianji) - includes all land over which the household has longterm control rights.
} 
Neither transitory nor permanent components are observed explicitly, so (3) and (4) are combined in (5) below. Note that the vector of village time dummies, $\mathbf{V}_{j \times t}$, is now used to pick up village-level events with an impact on both permanent and transitory components of income and village-wide components of measurement error. ${ }^{14}$

$$
y_{i j t}=\boldsymbol{\beta}_{1}^{\prime} \mathbf{h}_{i j t}+\boldsymbol{\beta}_{2}^{\prime} \mathbf{z}_{i j t}+\beta_{3} q_{i j t}+\boldsymbol{\alpha}\left(q_{i j t} \cdot s_{j t}\right)+\mathbf{V}_{j \times t}+u_{i j}+\epsilon_{i j t}
$$

Keeping in mind the likelihood that unobserved household effects will be of particular concern with this dataset, (5) can be first-differenced to eliminate the unobserved effects, yielding

$$
\Delta y_{i j t}=\boldsymbol{\beta}_{1}^{\prime} \Delta \mathbf{h}_{i j t}+\boldsymbol{\beta}_{2}^{\prime} \Delta \mathbf{z}_{i j t}+\beta_{3} \Delta q_{i j t}+\boldsymbol{\alpha} \Delta\left(q_{i j t} \cdot s_{j t}\right)+\mathbf{D}_{j \times t}+\varepsilon_{i j t}
$$

A new set of village year dummy variables, $\mathbf{D}_{j \times t}$, now identify all village level influences on the change in log income from year to year. The coefficient $\alpha$ allows us to pick up the idiosyncratic effect of rainfall shocks on the variability of household income. The results of this base specification are shown in the first columns of Tables 5 and 6 and discussed in Section 3.3 below.

\subsubsection{Identifying The Impact of Increased Access to Labor Markets}

Efforts to identify the impact of labor markets on household exposure to shocks must control for possible endogeneity of measured access to markets. Village-wide access to outside labor markets may be driven by the shocks themselves, by riskiness of the local environment, or by common expectations about future developments in the community. ${ }^{15}$ As in (6) above, village-year dummy variables may be used to control for the common effects that have an impact on village connection to outside markets. Introducing these common effects makes it

\footnotetext{
${ }^{14}$ Permanent and transitory components of error are combined such that $\epsilon_{i j t}=\epsilon_{i j t}^{P}+\epsilon_{i j t}^{T}$, and $\epsilon_{i j t}$ is assumed to be serially uncorrelated.

${ }^{15}$ The likelihood of this phenomenon is driven home in the regressions of change in log income per laborer presented in Table 4. Wealthy and middle tercile households show a fall in income per laborer with increased village participation off-farm. These regressions do not include village-time fixed effects, so it is likely that the change in migrant or collective employment may partially reflect the effects of a negative shock to the local economy.
} 
impossible to identify the effect of labor market access on the household's ability to smooth the aggregate effect of the shock, but it is still possible to identify the impact of increased employment opportunities by focussing on the idiosyncratic effect of the shock. First, allow the coefficient on the interaction term, $\Delta\left(q_{i j t} \cdot s_{j t}\right)$, to vary over time and across villages as in $\left(6^{\prime}\right)$.

$$
\Delta y_{i j t}=\boldsymbol{\beta}_{1}^{\prime} \Delta \mathbf{h}_{i j t}+\boldsymbol{\beta}_{2}^{\prime} \Delta \mathbf{z}_{i j t}+\beta_{3} \Delta q_{i j t}+\boldsymbol{\alpha}_{j t} \Delta\left(q_{i j t} \cdot s_{j t}\right)+\mathbf{D}_{j \times t}+\varepsilon_{i j t}
$$

Next, let $\boldsymbol{\alpha}_{j t}$ be a function of village-wide access to off-farm labor markets, $I_{j t}$, so that

$$
\boldsymbol{\alpha}_{j t}=\boldsymbol{\alpha}\left(1+I_{j t}\right)
$$

By introducing $I_{j t}$ as a further interaction with $\Delta\left(q_{i j t} \cdot s_{j t}\right)$ we have

$$
\begin{aligned}
\Delta y_{i j t} & =\boldsymbol{\beta}_{1}^{\prime} \Delta \mathbf{h}_{i j t}+\boldsymbol{\beta}_{2}^{\prime} \Delta \mathbf{z}_{i j t}+\beta_{3} \Delta q_{i j t}+\boldsymbol{\alpha}_{1} \Delta\left(q_{i j t} \cdot s_{j t}\right) \\
& +\boldsymbol{\alpha}_{2}\left[I_{t} \cdot \Delta\left(q_{i j t} \cdot s_{j t}\right)\right]+\mathbf{D}_{j \times t}+\varepsilon_{i j t}
\end{aligned}
$$

These two interaction terms allow us to identify the effect of growing access to local and distant labor markets on the ability of households to cope with shocks to income. ${ }^{16} \mathrm{~A}$ statistically significant coefficient $\boldsymbol{\alpha}_{2}$ opposite in sign from $\boldsymbol{\alpha}_{1}$ indicates that the effect of rainfall shocks on the variability of income is reduced with greater village access to the

\footnotetext{
${ }^{16}$ Using village level access to labor markets may appear blunt - it might seem preferable to separately identify household level effects of access to off-farm labor markets. Potential bias from unobserved household characteristics again arises in any effort to split the sample based on past participation in off-farm labor markets. If unobserved household effects are correlated with past labor market experience, then these unobserved characteristics may drive both lower observed variability of incomes and selection into participation in off-farm activities. In this case, a conclusion that households with past access to off-farm markets have less variable incomes would wrongly attribute the cause to labor market access rather than the unobserved characteristic. Such characteristics might include factors affecting household risk preferences such as the presence of family members in distant cities or towns that can aid in finding jobs and supplying additional sources of income in times of hardship, or some other characteristic that might improve prospects for smoothing of agricultural shocks.
} 
off-farm labor market. While measures of village access to labor markets will also be affected by shocks to the local economy or by current assessments of the riskiness of agricultural production, the village-year dummy variables control for these aggregate effects. The interaction terms allow identification of the impact of connection to off-farm markets controlling for the contemporaneous aggregate shock. Identification is achieved by concentrating on the idiosyncratic effect of the rainfall shock, and determining whether or not the corresponding idiosyncratic effect attenuates with increased village-wide access to off-farm markets.

Use of these village level market access variables offers an important benefit over use of geographic variables. ${ }^{17}$ Locational variables are clearly exogenous, but they are not necessarily an accurate reflection of connections between the village and outside labor markets. Other research on temporary migration in China notes the important role of information flows between source and destination communities (Meng, 1996). Connections with outside markets are not determined by geography alone, but through prior connection with potential employers outside the village. For this reason, connections to outside labor markets picked up by alternative indices, $I_{j t}$, provide more information than geographic measures alone.

\subsection{Results: Access to Labor Markets and the Variability of Household Income}

Results of specification $\left(6^{\prime}\right)$ and different implementations of (8) are shown in Tables 5 and 6. Interestingly, the effect of access to off-farm labor markets is only strongly significant when the sample is split by the lagged wealth per capita tercile of the household (Table 6). It is evident that households falling in the middle wealth tercile make the most use of both migrant and local off-farm labor markets as a means of reducing income variability. More affluent households that are better able to insure consumption out of savings are less likely

\footnotetext{
${ }^{17}$ Other research attmpting to control for the remoteness of villages often uses geographic variables (see, for example, Jalan and Ravallion, 1998). The RCRE village data contains both locational variables indicating whether the village is situated in mountains, hills or on the plain, or in the outskirts of cities, and distance of the village from main roads.
} 
to worry about smoothing the income effect of production shocks. Poorer households, on the other hand, may be poorer because they have less access to these labor markets due to either a low human capital endowment, demographic constraints on ability to work outside the village, geographic isolation, or poor information about jobs outside employment.

In addition, it is important to note that poorer households do not show significant variability of income as a result of idiosyncratic effects of the rainfall shock. This result may be driven by two factors: first, villages where less affluent households are located may be more homogenous in terms of the size of landholding, and this will mean that the idiosyncratic component of shock identified off of land-holding is not likely to be significant. Table 3 shows that the standard deviation of household landholding does not differ significantly from the other two wealth terciles. A second possibility may be that these households take ex ante precautions to limit exposure to changes in income prior to realization of rainfall shocks. As emphasized by Morduch $(1992,1995)$, credit constrained households with little ability to smooth consumption ex post may choose activities ex ante that limit exposure to risk.

When interpreting these results, the magnitudes of identified shock are clearly not large. For a household in the middle wealth tercile with average land area (6.92 $\mathrm{mu})$ and average income per laborer (836 RMB Yuan in 1997), the idiosyncratic effect of a two-standard deviation positive rainfall shock is just a loss of 16 Yuan. By increasing access to off-farm labor markets from zero to their average 1997 values, this shock is completely eliminated at the average share of migrant labor market participation for this tercile in 1997. Evaluating the effect of collective employment at 1997 average share of labor in collective employment, we find no attenuation of the effect of the shock. Finally, when local participants in private wage employment increase to the 1997 average of 13 percent, the effect of the shock drops to 3 Yuan RMB.

These significant, but relatively low magnitudes should be understood in light of the fact that this procedure is only identifying the impact of off-farm opportunities on the idiosyncratic effect of the aggregate shock. Much of the effect of the shock will be common across all households, but this common component and any average ability to smooth through the 
labor market is captured in the village-year dummy variables. Thus, the relatively small significant effect need not be dismissed if the effect of increased access to outside markets is similar for the aggregate component of shock.

\section{Consumption Variability and the Growth of Labor Mar- kets}

The most frequently employed test of how well households smooth consumption effects of income shocks uses the general framework of the full-insurance model laid out in Deaton (1992, 1997), and the testing strategy follows the general spirit of Townsend (1994, 1995), Cochrane(1991), Jalan and Ravallion (1997) and Gertler and Gruber (1997). This section looks at how access to off-farm labor markets affects household ability to smooth the effect of shocks on consumption. In a sense, the implementation of the model used here has more of a risk-sharing flavor typical of research on how well countries or regions within a country share risk through participation in capital markets (see, for example, Atkeson and Bayoumi, 1993). In rural China, access to capital markets is virtually non-existent, but the opening of cross-regional labor markets offer another means by which households can limit exposure to shocks or reduce their impact ex post.

\subsection{Access to Migrant Employment and Insurance Against Idiosyncratic Shocks}

The full-insurance model posits that while households in village communities lack access to formal insurance and credit markets, they may still be able to insure each other against the idiosyncratic shocks facing individual households. Opportunities for informal insurance exist because information flows within the village reduce the moral hazard and adverse selection problems that make it difficult for outside organizations to offer insurance at an affordable price. Households within the village know who has made efforts to reduce exposure to risk, and know when shocks are legitimate. Because households within the village are engaged in long-term relationships and have good information about one another, 
they are willing to effectively trade across states of nature ex ante so as to provide one another assistance in the case of hardship. If full insurance is available within a village, then the marginal utilities of consumption of households within the village will move together. Shocks to household consumption will track aggregate shocks experienced in the wider village, and idiosyncratic shocks affecting income of the household alone should have no effect on consumption Townsend (1994) and Deaton (1997).

Equation (9), below, shows the basic empirical relationship implied by the full insurance model. Here, $\Delta c_{i j t}$ represents the change in the log of household $i$ 's non-durable consumption per capita between years $t$ and $t-1, \Delta \bar{c}_{j t}$ is village $j$ 's change in log average consumption per capita, and $\Delta y_{i j t}$ is the log change in household income per capita. If a household is able to perfectly smooth the effects of idiosyncratic shocks to income, the coefficient on change in log household income, $\beta_{1}$, should not be statistically different from zero, and the coefficient on change in average village consumption, $\alpha_{1}$, should be one.

$$
\Delta c_{i j t}=\alpha_{1} \Delta \bar{c}_{j t}+\beta_{1} \Delta y_{i j t}+\varepsilon_{i j t}
$$

Chaudhuri and Ravallion (1997) have shown that coefficients on this model are biased, and that this bias can be corrected using village-year dummy variables to control for the effects of village level shocks. In addition, Jalan and Ravallion's (1997) study of consumption insurance in southwest China suggests that population size is endogenous and that this fact should also be taken into consideration when implementing a full-insurance test, as in (10) below.

$$
\Delta c_{i j t}=D_{v * t}+\beta_{1} \Delta y_{i j t}+\beta_{2} \Delta p o p_{i j t}+\varepsilon_{i j t}
$$

Households conceivably smooth shocks to income by sending family members to live with relatives outside of the village. Coefficients on change in log household population should be negative and significant, reflecting the fact that changes in the household population will have the effect of reducing the shock to per capita consumption within the household.

Specification (10) is typically estimated through instrumental variables methods in order to control for both measurement error bias and the endogeneity of household size. First, 
as pointed out by Deaton (1997) and others, the fact that the household's estimation of both consumption and income includes home produced grains and vegetables, errors in the valuation of income and consumption are likely to be correlated, and thus implying that errors measurement of the dependent variable will be correlated with errors in measurement of the change in log income. While one way of estimating (10) would be to follow Jalan and Ravallion (1999) and instrument for both measurement error in income and endogeneity of household size, it would be more direct to substitute the set of instruments directly for change in log income. ${ }^{18}$ This approach makes sense because if one has an instrument for shock other than the change in household's self reported income. Given that it is possible to directly estimate the affect of a shock to agricultural production, concerns of measurement error bias are also less important.

As an alternative, specification (11) below uses the same regressors from Section 3 above with change in the log of non-durable consumption as the dependent variable.

$$
\begin{aligned}
\Delta c_{i j t} & =\boldsymbol{\beta}_{1}^{\prime} \Delta \mathbf{h}_{i j t}+\boldsymbol{\beta}_{2}^{\prime} \Delta \mathbf{z}_{i j t}+\beta_{3} \Delta q_{i j t}+\boldsymbol{\alpha}_{1} \Delta\left(q_{i j t} \cdot s_{j t}\right) \\
& +\boldsymbol{\alpha}_{2}\left[I_{t} \cdot \Delta\left(q_{i j t} \cdot s_{j t}\right)\right]+\mathbf{D}_{j \times t}+\varepsilon_{i j t}
\end{aligned}
$$

As in Section 3.2, the effect of village access to off-farm migrant and local labor markets is picked up by introducing interactions of the rainfall shock and indices of market integration, $I_{j t}$. Again, the village*year fixed effects allow us to control for growth or shock at the level of the village.

\subsection{Results - Opening of Labor Markets and Ability to Smooth Shocks to Consumption}

Tables 7 and 8 show that expanded participation in off-farm labor markets also facilitates smoothing of consumption. Again, more affluent households are better able to benefit from these opportunities, suggesting that some components of non-durable consumption

\footnotetext{
${ }^{18}$ As mentioned above, the household size variable in our analysis follows a legal definition and does not change with shocks to income.
} 
among middle and upper tercile households are not absolute necessities. For middle tercile households, moving from a position of no access to the $75^{\text {th }}$ percentile FOR 1997 allows households with average land holdings to completely smooth the idiosyncratic effect of the shock.

As in Section 3, the actual magnitude of shocks associated with the idiosyncratic effect are quite small in magnitude. Even in isolated areas with low levels of integration in migrant or local labor markets, the average decline in consumption for households with mean farm-size is only two percent with a two-standard-deviation positive rainfall shock. Again, it is important to recognize that these specifications are only picking up the impact of the idiosyncratic component of shock, and both the size of the shock and the impact of access to markets will likely be more pronounced if the aggregate component could also be separately identified.

The effect of the shock may have serious implications if it results in shifts within household non-durable expenditures. For example, if shocks lead to reduced attendance in school when the labor of children is required back on the farm, then exposure to shock can have serious implications for investment in human capital. While the RCRE dataset lacks data on school attendance, it does report expenditures related to education. ${ }^{19}$ Table 9 shows the results of (11) with change in level of education expenditures per child as the dependent variable. The results of these models show that the shock has a significant effect on magnitudes of expenditure on education, and again, that participation in local labor markets results in an attenuation of this effect. If reduction of expenditures is correlated with reduced time in school because households require more labor on farm subsequent to the shock, then growth in local labor markets reduces the importance of this effect on investment in human capital. Increasing access to migrant employment is not associated with a similar smoothing of shocks to education expenditures. This makes sense if having family members outside the village at the time of the shock leads the household to rely more strongly on children's labor on farm.

\footnotetext{
${ }^{19}$ Education expenditures are not altogether satisfactory because reduced expenditure on books or supplies is not likely to be as important as reduced attendance in class.
} 
While greater village access to migrant employment brings the benefit of higher incomes and improved ability to smooth consumption, the failure to smooth variation in expenditures on education should be cause for concern. The opening of markets for migrant employment works to reduce the growth in income disparity across regions of rural China, but the possibility that education expenditures are no less variable with greater migrant employment suggests that children in these regions may be still be at a disadvantage due to more yearto-year variation in investment in human capital.

\section{Conclusions}

This paper shows that access to off-farm labor markets plays a potentially important role in reducing the income and consumption variability associated with shocks to agricultural

production. The expansion of privately operated enterprises in some areas of rural China is associated with both higher incomes, and greater ease of reducing the consumption and income effects of variable incomes. Greater access to the migrant employment opportunities also offers an important means of reducing income variability for some rural residents.

Results for rural residents in the poorest wealth tercile remain something of a puzzle - neither consumption nor income showed much variability in response to rainfall shocks. This observation could be driven by two factors. First, the analysis focussed on how well households smoothed the idiosyncratic effect of the aggregate rainfall shock. It is entirely plausible that there was simply not much variability in the idiosyncratic effect for poorer households in the sample. This could be driven by either the ex ante risk-reducing efforts of more exposed households, or by more efficient insurance among the households that are most exposed. Second, these households are concentrated in villages where access to the outside market has not increased as rapidly.

Attention to the potential risk-coping benefits from off-farm employment is timely for Chinese policymakers because both local and national policies accommodating the growth of markets for off-farm migrant labor have come under increasing pressure over the last two years. As cities face growing problems of unemployed workers from state-owned enterprises, both local and national governments take measures to reduce competition for jobs between 
rural laborers and those urban residents left unemployed in the wake of state-owned enterprise (SOE) reform. ${ }^{20}$ The analysis of this paper suggests that rural residents would suffer from urban policies restricting the in-flow of migrants in two ways. Households sending temporary migrants to cities will suffer both a loss of income, and a loss of insurance against the income effects of shocks on-farm. In fact, the analysis suggests that the welfare of Chinese farm households in rural communities can be further improved by eliminating the remaining institutional obstacles to expansion of migrant employment opportunities.

\footnotetext{
${ }^{20}$ Minutes of the Labor Mobility Forum, April and June 1998. The Labor Mobility Forum is a formal discussion group of policy research staff including representatives from the Development Research Center of the State Council, the Ministry of Labor, and the Ministry of Agriculture, and the Chinese Academy of Social Sciences.
} 


\section{Appendix - Rainfall Shocks and the Characterization of Risk}

In addition to the RCRE data, enumerators collected twenty years of monthly rainfall data from weather stations near each village in order to characterize purely exogenous shocks to the local agricultural economy. An eight-month rainfall shock was calculated as the difference between realized and expected rainfall where it was assumed that farmers may recognize a dry year or a wet year after observing rainfall in January and February. Expected eight-month rainfall $\hat{X}_{j t}$ in village $j$ of year $t$ was calculated using twenty years of monthly rainfall data for each of the 44 villages when running the regression:

$$
X_{j t}=D_{j}+\beta_{1} X_{j t}^{F e b}+\beta_{2} X_{j t}^{J a n}+\varepsilon_{j t}
$$

This specification allows some serial correlation between rainfall in the current eight-month period, $X_{j t}$ and rainfall observed in February and January, $X_{j t}^{F e b}$ and $X_{j t}^{J a n}$. Each of the $j$ regressions include a constant, $D_{j}$, to capture mean rainfall in the village. After controlling for correlation in rainfall realizations over the year, the error term $\varepsilon_{j t}$ is assumed to be independently distributed. The rainfall shock in season $s$, is then calculated as $X_{j t}^{S}=X_{j s t}-\hat{X}_{j s t}$. Calculating shocks in this way provides a better approximation of surprise changes in rainfall than using the difference between actual and mean rainfall for each season. ${ }^{21}$

\footnotetext{
${ }^{21}$ Shocks will appear larger, for example, if they are correlated over time but approximated as the difference between actual and mean seasonal rainfall.
} 
Figure 1

Share of Village Labor in Migrant Employment

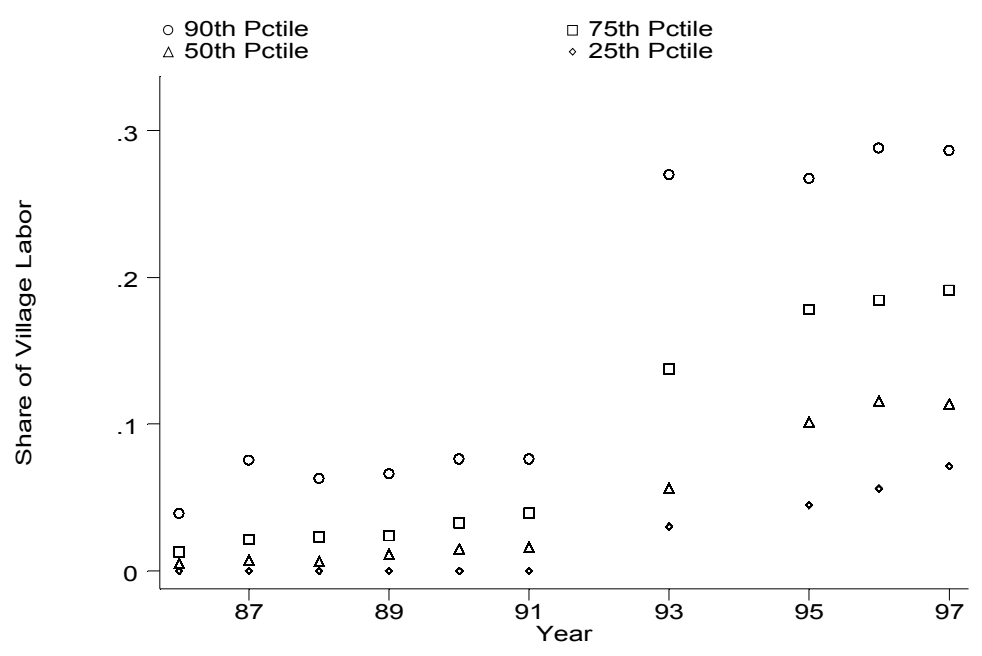

Figure 2

Share of Village Labor in Local Private

Wage Employment

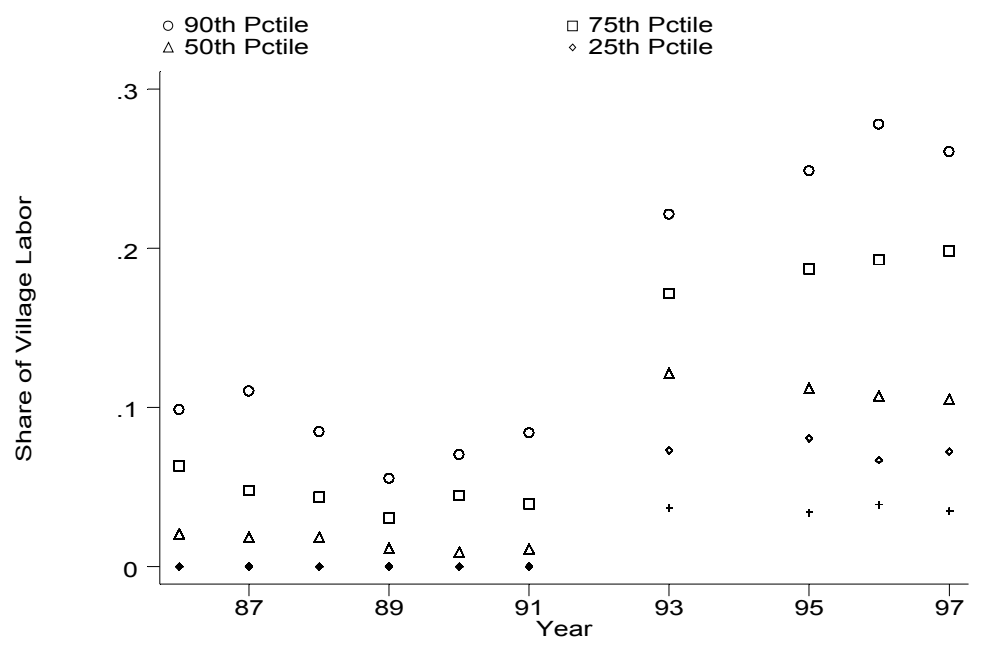


Figure 3

Share of Village Labor in Local

\section{Collective Employment}

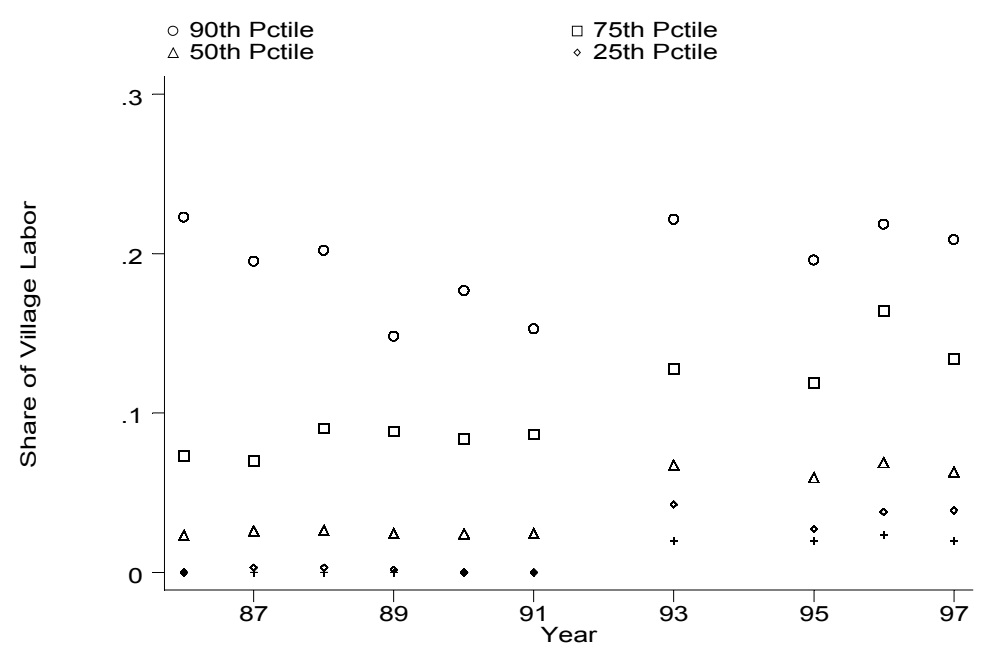




\section{References}

Alderman, Harold (1996). "Saving and Economic Shocks in Rural Pakistan," Journal of Development Economics, v51 n2 December 1996, pp. 343-65

Atkeson, Andrew and Tamim Bayoumi (1993). "Do Private Capital Markets Insure Regional Risk? Evidence from the United States and Europe." Open Economies Review 4, 1993.

Benjamin, Dwayne and Loren Brandt (1999). "Administrative Land Allocation, Nascent Labour Markets, and Farm Efficiency in Rural China." University of Toronto, mimeo, 1999.

Chaudhuri, Shubham and Martin Ravallion (1997), "Risk and Insurance in Village India: Comment," Econometrica; v65 n1 January 1997, pp. 171-84.

Chen, Hongyi (1997), "Economic Reform, Institutional Transition, and Firm Contractual Form Innovation: An Empirical Study on China's Township and Village Enterprises," Ph.D. Dissertation, UC Berkeley, 1997.

Chen, Shaohua and Martin Ravallion (1996), "Data in Transition: Assessing Rural Living Standards in Southern China," China Economic Review, Volume 7, Spring 1996

Coate and Ravallion (1993), "Reciprocity without Commitment: Characterization and Performance of Informal Insurance Arrangements," Journal of Development Economics, 40.

Deaton, Angus (1992). Understanding Consumption. Clarendon Press, Oxford, 1992.

Deaton, Angus (1997). The Analysis of Household Surveys: A Microeconometric Approach to Development Policy. The Johns Hopkins University Press, 1997.

Giles, John (2000). "Risk, Shock and Weak Property Rights in the Migration Decision of Rural Chinese Households." Mimeograph, Michigan State University, March 2000. 
Hare, Denise and Shukai Zhao (1996). "Labor Migration as a Rural Development Strategy: A View from the Migration Origin," Paper presented at the 1996 Conference on RuralUrban Migration, Beijing, June 21-23.

Jalan, Jyotsna and Martin Ravallion (1999), "Are the Poor Less Well Insured? Evidence on Vulnerability to Income Risk in Rural China," Journal of Development Economics, February, 1999.

Jalan, Jyotsna and Martin Ravallion (1998), "Geographic Poverty Traps? A Micro Model of Consumption Growth in Rural China," Mimeo, World Bank, November 1, 1998.

Kochar, Anjini (1999). "Smoothing Consumption by Smoothing Income: Hours-of-Work Responses to Idiosyncratic Agricultural Shocks in Rural India," Review of Economics and Statistics; v81 n1 February 1999, pp. 50-61.

Lin, Justin Yifu (1992). "Rural Reforms and Agricultural Growth in China," American Economic Review, 82(1).

Macmillan, John, J. Whalley and Ling Zhu (1989). "The Impact of China's Economic Reforms on Agricultural Productivity Growth," Journal of Political Economy, 97.

Meng, Xin (1996). "Regional Wage Gap, Information Flow, and Rural-Urban Migration," Paper presented at the 1996 Conference on Rural-Urban Migration, Beijing, June 21-23.

Morduch, Jonathan (1992). "Risk, Production, and Saving. Theory and Evidence from Indian Households." mimeo, original version 1990, revised version June 1992.

Morduch, Jonathan (1995). "Income Smoothing and Consumption Smoothing" in Journal of Economic Perspectives, 9(3), Summer 1995.

Morduch, Jonathan and Terry Sicular (1996). "On the Four Major Relationships Concerning Income Distribution in Rural China.” draft mimeograph, March 1996. 
Paulson, Anna (1994). "Insurance Motives for Migration: Evidence from Thailand," Ph.D. Dissertation, University of Chicago 1994.

Park, Albert, Sangui Wang, and Guobao Wu (1997). "Assessing China's War on Poverty," University of Michigan, draft April 1997.

Park, Albert, Loren Brandt, and John Giles (1997). "Giving Credit Where Credit is Due: The Changing Role of Rural Financial Institutions in China." The Davidson Institute Working Paper Series. University of Michigan. Number 71, March 1997.

Parrish, William, Xiaoye Zhe, and Fang Li (1995). "Nonfarm Work and Marketization of the Chinese Countryside," in China Quarterly 143: 697-730.

Paxson, Christina H. (1992). "Using Weather Variability to Estimate the Response of Savings to Transitory Income in Thailand." American Economic Review, 82(1).

Putterman, Louis (1993). Continuity and Change in China's Rural Development: Collective and Reform Eras in Perspective. Oxford University Press, New York, 1993.

Rose, Elaina (1995). "Ex Ante and Ex Post Labor Responses to Risk in a Low-Income Area," mimeo, June 1995.

Rosenzweig, M. and Binswanger, H. (1993) "Wealth, Weather Risk and the Composition and Profitability of Agricultural Investments," Economic Journal, 103, January 1993.

Rosenzweig, M. and Oded Stark (1989). "Consumption Smoothing, Migration, and Marriage: Evidence from Rural India," Journal of Political Economy, August 1989, 97(4).

Rozelle, Scott (1996). "Stagnation without Equity: Patterns of Growth and Inequality in China's Rural Economy," The China Journal 35: 63-92.

Rozelle, Scott and Leying Jiang (1994), "Survival Strategies and Recession in Rural Jiangsu," The China Quarterly. 
Rozelle, Scott, Li Guo, Shen Minggao, et al (1999). "Leaving China's Farms: Survey Results of New Paths and Remaining Hurdles to Rural Migration," The China Quarterly (1999).

Townsend, Robert (1994). "Risk and Insurance in Village India," Econometrica, 62:3.

Udry, Christopher (1994). "Risk and Insurance in a Rural Credit Market: An Empirical Investigation in Northern Nigeria," Review of Economic Studies, 61.

Udry, Christopher (1995). " "Risk and Saving in Northern Nigeria," American Economic Review; v85 n5 December 1995, pp. 1287-1300.

Wang, Feng and Xuejin Zuo (1999). "Inside China's Cities: Institutional Barriers and Opportunities for Urban Migrants." American Economic Review, Papers and Proceedings, May 1999.

Yang, Mayfair Mei-Hui (1994). Gifts, Favors and Banquets: The Art of Social Relationships in China, Cornell University Press, Ithaca.

Zhang, Xiaohui, Hansheng Chen, and Zhigang Wu (1996). "Chuantong Nongqu Nonghu Jianye Xianzhuang yu Xiaoyi Bijiao Yanjiu" [A Comparative Study of the Present Situation and Benefits of Rural Household Sideline Activities in Traditional Agricultural Regions], Nongcun Jingji Yanjiu Cankao [Research on Rural Economy Reference (Papers)], Ministry of Agriculture, Research Centre on the Rural Economy, Beijing. 1996:4.

Zhang, Xiaohui, Changbao Zhao, and Liangbiao Chen (1995). "1994: Nongcun Laodongli Kua Quyu Liudong di Shezheng Miaoshu" [1994: A Real Description of Rural Labors CrossRegional Flow], Zhanlue Yu Guanli [Strategy and Management], Beijing, 6:27-35. 
Table 1

Summary Information on 44 RCRE Villages

Surveyed Annually Between 1986 and 1997

\begin{tabular}{|c|c|c|c|c|}
\hline & \multicolumn{4}{|c|}{ Province } \\
\hline & Shanxi & Jiangsu & Anhui & Henan \\
\hline Total Number of Villages & 10 & 6 & 14 & 14 \\
\hline Near a City or County Seat & 1 & 0 & 2 & 1 \\
\hline \multicolumn{5}{|l|}{ Distance to Nearest } \\
\hline Nearest & 1 & 1 & 0 & 0 \\
\hline Median & 2.5 & 1 & 2 & 1.5 \\
\hline Most Distant & 6 & 1 & 8 & 15 \\
\hline Number of Villages on a Plain & 3 & 4 & 5 & 7 \\
\hline Number of Villages in a Hilly Area & 2 & 2 & 6 & 3 \\
\hline Number of Villages in a Mountainous Area & 5 & 0 & 3 & 4 \\
\hline Average Number of Households & 305 & 314 & 353 & 383 \\
\hline Average Number of Households Surveyed & 97 & 71 & 68 & 74 \\
\hline Average Village Population & 1128 & 1111 & 1402 & 1623 \\
\hline Average Number of Prime Age Laborers* & 545 & 626 & 764 & 859 \\
\hline $\begin{array}{l}1987 \\
\text { Average Income Per Adult Laborer (in } 1986 \\
\text { RMB Yuan) }\end{array}$ & 571 & 1078 & 690 & 574 \\
\hline $\begin{array}{l}\text { Average Non-Durable Consumption Per } \\
\text { Capita (in } 1986 \text { RMB Yuan) }\end{array}$ & 307 & 644 & 442 & 359 \\
\hline $\begin{array}{l}\text { Average Education Expenditures Per Child } \\
\text { (in } 1986 \text { RMB Yuan) }\end{array}$ & 6.7 & 12.3 & 8.5 & 6.8 \\
\hline $\begin{array}{l}1997 \\
\text { Average Income Per Adult Laborer (in } 1986 \\
\text { RMB Yuan) }\end{array}$ & 846 & 1322 & 869 & 814 \\
\hline $\begin{array}{l}\text { Average Non-Durable Consumption Per } \\
\text { Capita (in } 1986 \text { RMB Yuan) }\end{array}$ & 432 & 847 & 566 & 462 \\
\hline $\begin{array}{l}\text { Average Education Expenditures Per Child } \\
\text { (in } 1986 \text { RMB Yuan) }\end{array}$ & 28.5 & 103.8 & 42.3 & 39.1 \\
\hline
\end{tabular}

*Prime age laborers are men between the ages of 15 and 60 and women between 15 and 55 who are working full time. 
Table 2

Summary Information by Wealth Tercile

\begin{tabular}{|c|c|c|c|c|c|c|}
\hline & 1987 & 1989 & 1991 & 1993 & 1995 & 1997 \\
\hline \multicolumn{7}{|l|}{ Wealthiest Tercile } \\
\hline Household Size & 4.4 & 4.4 & 4.3 & 4.1 & 4.1 & 3.9 \\
\hline Adult Laborers & 2.5 & 2.5 & 2.5 & 2.5 & 2.5 & 2.4 \\
\hline Income Per Laborer & 830 & 853 & 771 & 920 & 1103 & 1204 \\
\hline Consumption Per Capita & 470 & 486 & 466 & 518 & 657 & 657 \\
\hline Village Migrant Share & 0.03 & 0.03 & 0.03 & 0.08 & 0.10 & 0.11 \\
\hline Village Collective Share & 0.11 & 0.12 & 0.13 & 0.16 & 0.15 & 0.16 \\
\hline Village Private Wage Share & 0.03 & 0.04 & 0.05 & 0.16 & 0.13 & 0.14 \\
\hline \multicolumn{7}{|l|}{ Middle Tercile } \\
\hline Household Size & 4.7 & 4.7 & 4.5 & 4.4 & 4.2 & 4.2 \\
\hline Adult Laborers & 2.6 & 2.6 & 2.6 & 2.7 & 2.6 & 2.6 \\
\hline Income Per Laborer & 637 & 568 & 520 & 633 & 795 & 836 \\
\hline Consumption Per Capita & 381 & 369 & 367 & 388 & 734 & 504 \\
\hline Village Migrant Share & 0.02 & 0.02 & 0.03 & 0.10 & 0.12 & 0.14 \\
\hline Village Collective Share & 0.08 & 0.07 & 0.08 & 0.11 & 0.09 & 0.09 \\
\hline Village Private Wage Share & 0.06 & 0.04 & 0.04 & 0.11 & 0.13 & 0.13 \\
\hline \multicolumn{7}{|l|}{ Bottom Tercile } \\
\hline Household Size & 4.7 & 4.5 & 4.4 & 4.3 & 4.1 & 4.1 \\
\hline Adult Laborers & 2.4 & 2.5 & 2.4 & 2.4 & 2.4 & 2.4 \\
\hline Income Per Laborer & 462 & 429 & 388 & 487 & 599 & 623 \\
\hline Consumption Per Capita & 324 & 315 & 300 & 342 & 423 & 407 \\
\hline Village Migrant Share & 0.02 & 0.02 & 0.03 & 0.14 & 0.16 & 0.18 \\
\hline Village Collective Share & 0.04 & 0.03 & 0.04 & 0.09 & 0.07 & 0.08 \\
\hline Village Private Wage Share & 0.04 & 0.03 & 0.04 & 0.12 & 0.15 & 0.14 \\
\hline
\end{tabular}

Village share measures are calculated from the RCRE village survey form. 
Table 3

Household and Village Variables Used as Regressors

(Standard Deviations in Parentheses)

\begin{tabular}{|c|c|c|c|c|}
\hline Regressors & Overall & Wealthiest Tercile & Middle Tercile & Poorest Tercile \\
\hline Male Prime Age Labor & $\begin{array}{l}1.305 \\
(0.736)\end{array}$ & $\begin{array}{c}1.269 \\
(0.750)\end{array}$ & $\begin{array}{l}1.362 \\
(0.742)\end{array}$ & $\begin{array}{l}1.297 \\
(0.706)\end{array}$ \\
\hline Female Prime Age Labor & $\begin{array}{c}1.152 \\
(0.698)\end{array}$ & $\begin{array}{c}1.141 \\
(0.678)\end{array}$ & $\begin{array}{c}1.2 \\
(0.711)\end{array}$ & $\begin{array}{l}1.118 \\
(0.709)\end{array}$ \\
\hline Dependents & $\begin{array}{l}1.832 \\
(1.190)\end{array}$ & $\begin{array}{l}1.776 \\
(1.165)\end{array}$ & $\begin{array}{l}1.838 \\
(1.199)\end{array}$ & $\begin{array}{l}1.902 \\
(1.210)\end{array}$ \\
\hline $\begin{array}{l}\text { Share of Labor with } \\
\text { Elementary Education }\end{array}$ & $\begin{array}{c}0.366 \\
(0.338)\end{array}$ & $\begin{array}{c}0.355 \\
(0.342)\end{array}$ & $\begin{array}{c}0.36 \\
(0.330)\end{array}$ & $\begin{array}{c}0.388 \\
(0.341)\end{array}$ \\
\hline $\begin{array}{l}\text { Share of Labor w/ Lower } \\
\text { Middle School }\end{array}$ & $\begin{array}{c}0.32 \\
(0.329)\end{array}$ & $\begin{array}{c}0.335 \\
(0.340)\end{array}$ & $\begin{array}{c}0.331 \\
(0.324)\end{array}$ & $\begin{array}{c}0.287 \\
(0.315)\end{array}$ \\
\hline $\begin{array}{l}\text { Share of Labor w/ Upper } \\
\text { Middle School }\end{array}$ & $\begin{array}{c}0.066 \\
(0.185)\end{array}$ & $\begin{array}{c}0.08 \\
(0.202)\end{array}$ & $\begin{array}{c}0.062 \\
(0.177)\end{array}$ & $\begin{array}{c}0.052 \\
(0.166)\end{array}$ \\
\hline $\begin{array}{l}\text { Share of Labor w/ Special } \\
\text { Skill }\end{array}$ & $\begin{array}{c}0.103 \\
(0.209)\end{array}$ & $\begin{array}{c}0.134 \\
(0.235)\end{array}$ & $\begin{array}{c}0.092 \\
(0.193)\end{array}$ & $\begin{array}{c}0.073 \\
(0.177)\end{array}$ \\
\hline $\begin{array}{l}\text { Land Managed by } \\
\text { Household (mu) }\end{array}$ & $\begin{array}{c}6.517 \\
(5.110)\end{array}$ & $\begin{array}{l}6.721 \\
(5.315)\end{array}$ & $\begin{array}{c}6.92 \\
(5.084)\end{array}$ & $\begin{array}{c}5.819 \\
(4.769)\end{array}$ \\
\hline Number of Plots & $\begin{array}{c}6.563 \\
(4.712)\end{array}$ & $\begin{array}{l}6.351 \\
(4.317)\end{array}$ & $\begin{array}{c}6.443 \\
(4.629)\end{array}$ & $\begin{array}{c}6.982 \\
(5.261)\end{array}$ \\
\hline Rainfall Shocks (100mm) & $\begin{array}{l}0.0534 \\
(2.179)\end{array}$ & $\begin{array}{l}0.011 \\
(2.065)\end{array}$ & $\begin{array}{c}0.087 \\
(2.148)\end{array}$ & $\begin{array}{c}0.153 \\
(2.355)\end{array}$ \\
\hline $\begin{array}{l}\text { Share of Village Labor in } \\
\text { Migrant Employment }\end{array}$ & $\begin{array}{c}0.062 \\
(0.087)\end{array}$ & $\begin{array}{l}0.048 \\
(0.064)\end{array}$ & $\begin{array}{c}0.065 \\
(0.087)\end{array}$ & $\begin{array}{c}0.08 \\
(0.108)\end{array}$ \\
\hline $\begin{array}{l}\text { Share of Village Labor in } \\
\text { Local Collective }\end{array}$ & $\begin{array}{c}0.093 \\
(0.136)\end{array}$ & $\begin{array}{c}0.125 \\
(0.167)\end{array}$ & $\begin{array}{c}0.085 \\
(0.125)\end{array}$ & $\begin{array}{l}0.057 \\
(0.076)\end{array}$ \\
\hline $\begin{array}{l}\text { Share of Village Labor in } \\
\text { Local Private Enterprise }\end{array}$ & $\begin{array}{c}0.075 \\
(0.094)\end{array}$ & $\begin{array}{c}0.071 \\
(0.096)\end{array}$ & $\begin{array}{c}0.079 \\
(0.095)\end{array}$ & $\begin{array}{c}0.077 \\
(0.091)\end{array}$ \\
\hline
\end{tabular}




\section{Table 4}

\section{The Impact of Aggregate Rainfall Shocks, and Access to Off-Farm Labor Markets on Household Income}

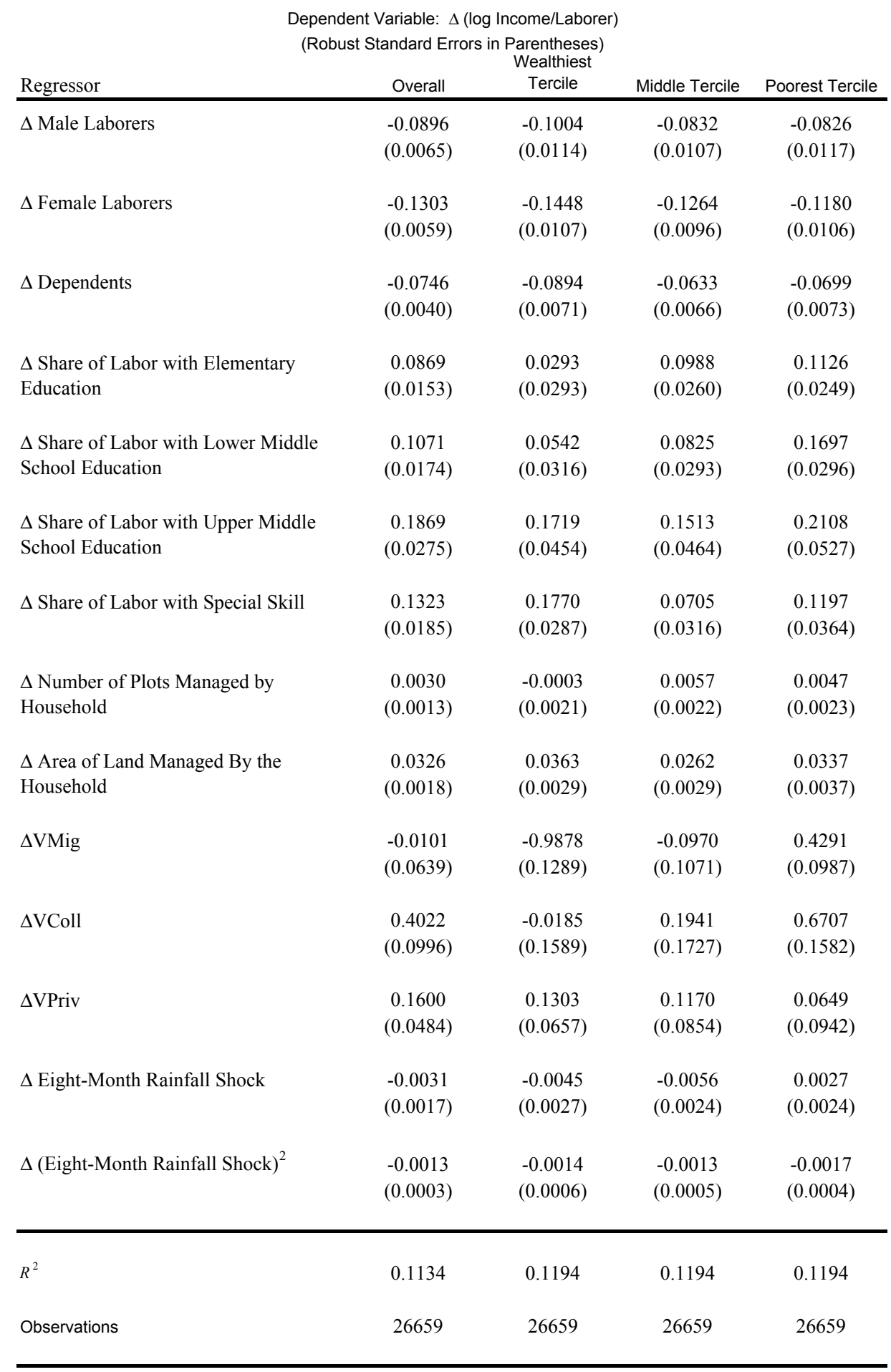

Note: The specification includes village and province*year dummy variables that are jointly significant. 
Table 5

Village Access to Off-Farm Labor Markets and the Variability of Household Income

\begin{tabular}{|c|c|c|c|c|c|}
\hline \multirow[b]{2}{*}{ Regressor } & \multicolumn{3}{|c|}{$\begin{array}{l}\text { Dependent Variable: } \Delta \text { (log Income/Laborer) } \\
\text { (Robust Standard Errors in Parentheses) }\end{array}$} & \multirow[b]{2}{*}{$(4)$} & \multirow[b]{2}{*}{ (5) } \\
\hline & (1) & $(2)$ & $(3)$ & & \\
\hline$\Delta$ Male Laborers & $\begin{array}{l}-0.0874 \\
(0.0062)\end{array}$ & $\begin{array}{l}-0.0874 \\
(0.0062)\end{array}$ & $\begin{array}{l}-0.0873 \\
(0.0062)\end{array}$ & $\begin{array}{l}-0.0873 \\
(0.0062)\end{array}$ & $\begin{array}{l}-0.0873 \\
(0.0062)\end{array}$ \\
\hline$\Delta$ Female Laborers & $\begin{array}{l}-0.1281 \\
(0.0056)\end{array}$ & $\begin{array}{l}-0.1281 \\
(0.0056)\end{array}$ & $\begin{array}{l}-0.1281 \\
(0.0056)\end{array}$ & $\begin{array}{l}-0.1281 \\
(0.0056)\end{array}$ & $\begin{array}{l}-0.1281 \\
(0.0056)\end{array}$ \\
\hline$\Delta$ Dependents & $\begin{array}{l}-0.0733 \\
(0.0038)\end{array}$ & $\begin{array}{l}-0.0734 \\
(0.0039)\end{array}$ & $\begin{array}{l}-0.0733 \\
(0.0038)\end{array}$ & $\begin{array}{l}-0.0733 \\
(0.0038)\end{array}$ & $\begin{array}{l}-0.0733 \\
(0.0038)\end{array}$ \\
\hline $\begin{array}{l}\Delta \text { Share of Labor with Elementary } \\
\text { Education }\end{array}$ & $\begin{array}{c}0.0915 \\
(0.0146)\end{array}$ & $\begin{array}{c}0.0916 \\
(0.0146)\end{array}$ & $\begin{array}{c}0.0915 \\
(0.0146)\end{array}$ & $\begin{array}{c}0.0916 \\
(0.0146)\end{array}$ & $\begin{array}{c}0.0915 \\
(0.0146)\end{array}$ \\
\hline $\begin{array}{l}\Delta \text { Share of Labor with Lower Middle } \\
\text { School Education }\end{array}$ & $\begin{array}{c}0.1058 \\
(0.0165)\end{array}$ & $\begin{array}{c}0.1058 \\
(0.0165)\end{array}$ & $\begin{array}{c}0.1058 \\
(0.0165)\end{array}$ & $\begin{array}{c}0.1060 \\
(0.0165)\end{array}$ & $\begin{array}{c}0.1059 \\
(0.0165)\end{array}$ \\
\hline $\begin{array}{l}\Delta \text { Share of Labor with Upper Middle } \\
\text { School Education }\end{array}$ & $\begin{array}{c}0.1886 \\
(0.0260)\end{array}$ & $\begin{array}{c}0.1887 \\
(0.0260)\end{array}$ & $\begin{array}{c}0.1887 \\
(0.0260)\end{array}$ & $\begin{array}{c}0.1890 \\
(0.0260)\end{array}$ & $\begin{array}{c}0.1889 \\
(0.0260)\end{array}$ \\
\hline$\Delta$ Share of Labor with Special Skill & $\begin{array}{c}0.1516 \\
(0.0179)\end{array}$ & $\begin{array}{c}0.1517 \\
(0.0179)\end{array}$ & $\begin{array}{c}0.1513 \\
(0.0179)\end{array}$ & $\begin{array}{c}0.1515 \\
(0.0179)\end{array}$ & $\begin{array}{c}0.1512 \\
(0.0179)\end{array}$ \\
\hline $\begin{array}{l}\Delta \text { Number of Plots Managed by } \\
\text { Household }\end{array}$ & $\begin{array}{c}0.0035 \\
(0.0012)\end{array}$ & $\begin{array}{c}0.0035 \\
(0.0012)\end{array}$ & $\begin{array}{c}0.0035 \\
(0.0012)\end{array}$ & $\begin{array}{c}0.0035 \\
(0.0012)\end{array}$ & $\begin{array}{c}0.0035 \\
(0.0012)\end{array}$ \\
\hline $\begin{array}{l}\Delta \text { Area of Land Managed By the } \\
\text { Household }\end{array}$ & $\begin{array}{c}0.0328 \\
(0.0017)\end{array}$ & $\begin{array}{c}0.0328 \\
(0.0017)\end{array}$ & $\begin{array}{c}0.0328 \\
(0.0017)\end{array}$ & $\begin{array}{c}0.0328 \\
(0.0017)\end{array}$ & $\begin{array}{c}0.0328 \\
(0.0017)\end{array}$ \\
\hline $\begin{array}{l}\Delta[(\text { Area of Land Managed By the } \\
\text { Household }) *(\text { Rainfall Shock })]\end{array}$ & $\begin{array}{l}-0.0007 \\
(0.0003)\end{array}$ & $\begin{array}{l}-0.0009 \\
(0.0004)\end{array}$ & $\begin{array}{l}-0.0009 \\
(0.0004)\end{array}$ & $\begin{array}{l}-0.0011 \\
(0.0005)\end{array}$ & $\begin{array}{l}-0.0011 \\
(0.0005)\end{array}$ \\
\hline $\begin{array}{l}{[\Delta(\text { Area of Land Managed By the }} \\
\text { Household }) *(\text { Rainfall Shock) }]^{*} \text { VMig }\end{array}$ & & $\begin{array}{c}0.0041 \\
(0.0043)\end{array}$ & & & \\
\hline $\begin{array}{l}{[\Delta(\text { Area of Land Managed By the }} \\
\text { Household }) *(\text { Rainfall Shock })]^{*} \text { VColl }\end{array}$ & & & $\begin{array}{c}0.0022 \\
(0.0023)\end{array}$ & & \\
\hline $\begin{array}{l}{[\Delta \text { (Area of Land Managed By the }} \\
\text { Household)*(Rainfall Shock) }]^{*} \text { VPriv }{ }_{t}\end{array}$ & & & & $\begin{array}{c}0.0056 \\
(0.0041)\end{array}$ & \\
\hline $\begin{array}{l}{[\Delta(\text { Area of Land Managed By the }} \\
\text { Household }) *(\text { Rainfall Shock })]^{*} \text { VLoc }\end{array}$ & & & & & $\begin{array}{c}0.0026 \\
(0.0019)\end{array}$ \\
\hline$R^{2}$ & 0.2217 & 0.2218 & 0.2228 & 0.2228 & 0.2228 \\
\hline Observations & 26659 & 26659 & 26659 & 26659 & 26659 \\
\hline
\end{tabular}

Notes: Male and female laborers and dependents are long-term members of the household. The land managed by the household is land contracted to the household over the long-term and does not vary with shocks. Not shown but jointly significant are village*time dummy variables. 
Tables 6.1 - 6.5

\section{Village Access to Off-Farm Labor Markets and the Variability of Household Income By Household Wealth}

\subsection{Base Regression}

Lagged Household Wealth Tercile

Regressor

High

Medium

Low

(1) $\Delta[$ (Area of Land Managed By the

$-0.0010$

$-0.0006$

0.0002

Household)*(Rainfall Shock)]

$(0.0004)$

$(0.0004)$

(0.0005)

F-Test (Coefficients on (1) Equal ?)

3.74

F-Prob

0.0238

\subsection{Village Access to Migrant Markets}

\begin{tabular}{lccc} 
& \multicolumn{3}{c}{ Lagged Household Wealth Tercile } \\
Regressor & High & Medium & Low \\
\hline (1) $\Delta[($ Area of Land Managed By the & -0.0015 & -0.0011 & 0.0006 \\
Household)*(Rainfall Shock)] & $(0.0005)$ & $(0.0005)$ & $(0.0006)$ \\
(2) $[\Delta($ Area of Land Managed By the & 0.0078 & 0.0079 & -0.0054 \\
Household)(Rainfall Shock) ${ }^{*}$ VMig $_{t}$ & $(0.0057)$ & $(0.0048)$ & $(0.0050)$ \\
\hline F-Test (Coefficients on (1) Equal ?) & 8.2 & & \\
F-Prob & 0.0003 & & \\
F-Test (Coefficients on (2) Equal ?) & 5.71 & & \\
F-Prob & 0.0033 & & \\
\hline
\end{tabular}

\subsection{Village Access to Local Wage Employment in Collective Enterprises}

\begin{tabular}{|c|c|c|c|}
\hline \multirow[b]{2}{*}{ Regressor } & \multicolumn{3}{|c|}{ Lagged Household Wealth Tercile } \\
\hline & High & Medium & Low \\
\hline $\begin{array}{l}\text { (1) } \Delta[\text { (Area of Land Managed By the } \\
\text { Household)*(Rainfall Shock) }]\end{array}$ & $\begin{array}{l}-0.0014 \\
(0.0005)\end{array}$ & $\begin{array}{l}-0.0010 \\
(0.0005)\end{array}$ & $\begin{array}{c}0.0003 \\
(0.0006)\end{array}$ \\
\hline $\begin{array}{l}\text { (2) }[\Delta \text { (Area of Land Managed By the } \\
\text { Household)*(Rainfall Shock) }]^{*} \text { VColl }_{t}\end{array}$ & $\begin{array}{c}0.0033 \\
(0.0025)\end{array}$ & $\begin{array}{c}0.0038 \\
(0.0028)\end{array}$ & $\begin{array}{l}-0.0027 \\
(0.0038)\end{array}$ \\
\hline $\begin{array}{l}\text { F-Test (Coefficients on (1) Equal ?) } \\
\text { F-Prob }\end{array}$ & $\begin{array}{c}5.19 \\
0.0056\end{array}$ & & \\
\hline $\begin{array}{l}\text { F-Test (Coefficients on (2) Equal ?) } \\
\text { F-Prob }\end{array}$ & $\begin{array}{c}1.62 \\
0.1973\end{array}$ & & \\
\hline
\end{tabular}

Specifications 6.1-6.5 run the same specifications as in Table 5, but the entire sample is split. The only coefficients shown are those related to the idiosyncratic effect of the rainfall shock. 
Tables $6.4-6.5$

6.4 Village Access to Local Wage Employment in Private Enterprises

\begin{tabular}{lccc} 
& \multicolumn{3}{c}{ Lagged Household Wealth Tercile } \\
Regressor & High & Medium & Low \\
\hline (1) $\Delta[($ Area of Land Managed By the & -0.0013 & -0.0012 & 0.0003 \\
Household)*(Rainfall Shock)] & $(0.0005)$ & $(0.0005)$ & $(0.0006)$ \\
& & & \\
(2) $[\Delta$ (Area of Land Managed By the & 0.0043 & 0.0081 & -0.0013 \\
Household)*(Rainfall Shock) VPriv $_{t}$ & $(0.0050)$ & $(0.0046)$ & $(0.0053)$ \\
& & & \\
F-Test (Coefficients on (1) Equal ?) & 4.84 & & \\
F-Prob & 0.0079 & & \\
F-Test (Coefficients on (2) Equal ?) & 2.16 & & \\
F-Prob & 0.1154 & & \\
& & & \\
\hline
\end{tabular}

6.5 Village Access to Local Wage Employment

\begin{tabular}{lccc} 
& \multicolumn{3}{c}{ Lagged Household Wealth Tercile } \\
Regressor & High & Medium & Low \\
\hline$\Delta[$ (Area of Land Managed By the & -0.0016 & -0.0013 & 0.0003 \\
Household)*(Rainfall Shock)] & $(0.0006)$ & $(0.0005)$ & $(0.0007)$ \\
& & & \\
{$[\Delta$ (Area of Land Managed By the } & 0.0031 & 0.0043 & -0.0017 \\
Household)*(Rainfall Shock) ${ }^{*}$ VLoc & $(0.0021)$ & $(0.0022)$ & $(0.0028)$ \\
& & & \\
F-Test (Coefficients on (1) Equal ?) & 5.94 & & \\
F-Prob & 0.0026 & & \\
F-Test (Coefficients on (2) Equal ?) & & & \\
F-Prob & 2.83 & & \\
\end{tabular}

Specifications 6.1-6.5 run the same specifications as in Table 5, but the entire sample is split. The only coefficients shown are those related to the idiosyncratic effect of the rainfall shock. 


\section{Table 7}

\section{Village Access to Off-Farm Labor Markets and the Variability of Non-Durable Consumption}

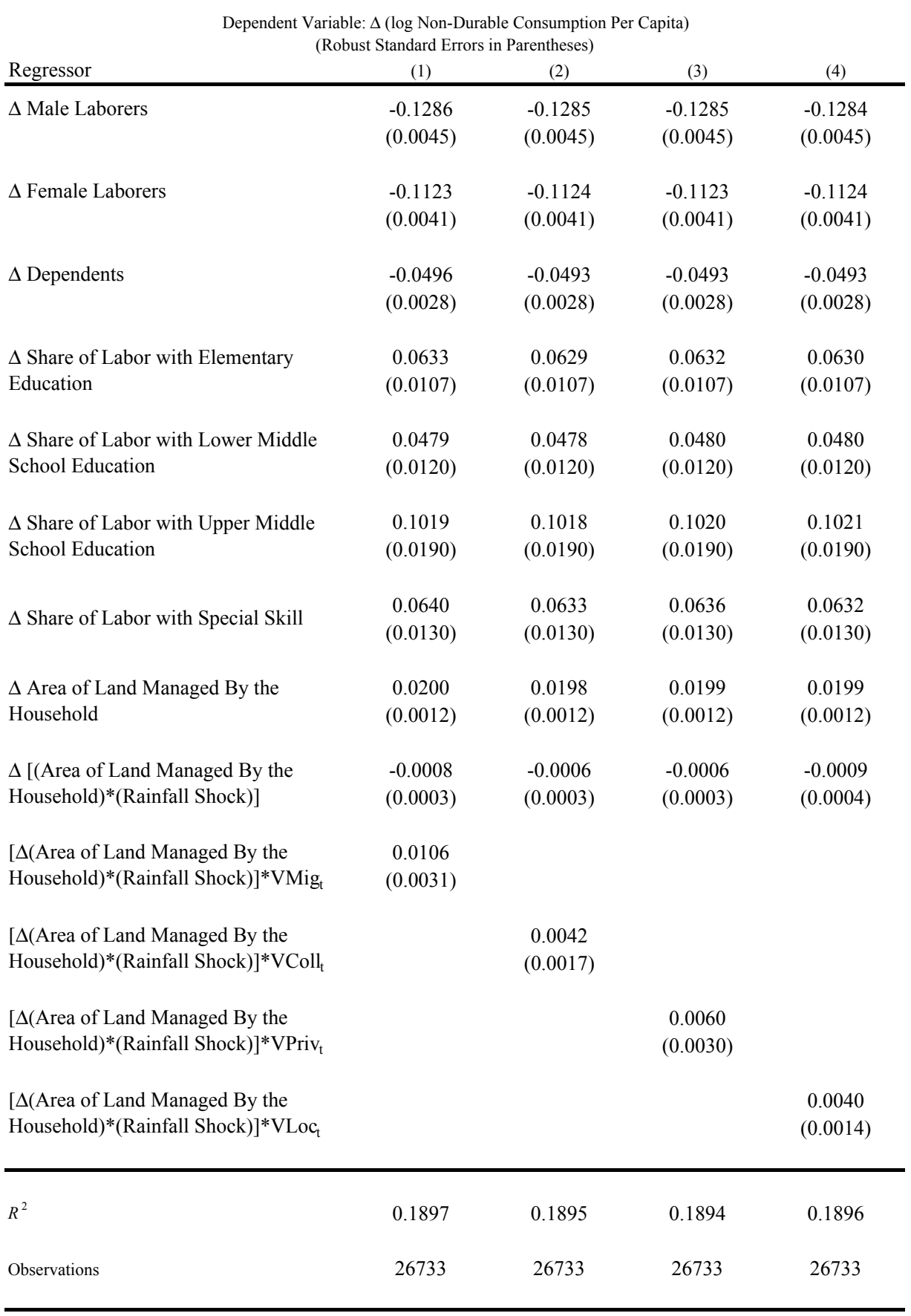

Notes: Male and female laborers and dependents are long-term members of the household. The land managed by the household is land contracted to the household over the long-term and does not vary with shocks. Not shown but jointly significant are village*time dummy variables. 
Tables 8.1 -8.5

\section{Village Access to Off-Farm Labor Markets and the Variability of Non-Durable Consumption By Lagged Household Wealth Tercile}

\subsection{Base Regression}

\begin{tabular}{lccc} 
& \multicolumn{3}{c}{ Lagged Household Wealth Tercile } \\
Regressor & High & Medium & Low \\
\hline (1) $\Delta[($ Area of Land Managed By the & -0.0004 & -0.0001 & 0.0000 \\
Household)*(Rainfall Shock)] & $(0.0003)$ & $(0.0003)$ & $(0.0000)$ \\
\hline F-Test (Coefficients on (1) Equal ?) & 3.15 & & \\
F-Prob & 0.0428 & & \\
\hline
\end{tabular}

\subsection{Village Access to Migrant Markets}

\begin{tabular}{lccc} 
& \multicolumn{3}{c}{ Lagged Household Wealth Tercile } \\
Regressor & High & Medium & Low \\
\hline (1) $\Delta[($ Area of Land Managed By the & -0.0009 & -0.0008 & -0.0003 \\
Household)*(Rainfall Shock)] & $(0.0004)$ & $(0.0004)$ & $(0.0004)$ \\
(2) $[\Delta$ (Area of Land Managed By the & 0.0071 & 0.0118 & 0.0101 \\
Household)*(Rainfall Shock)]*VMig & $(0.0042)$ & $(0.0035)$ & $(0.0037)$ \\
\hline F-Test (Coefficients on (1) Equal ?) & 1.26 & & \\
F-Prob & 0.2833 & & \\
F-Test (Coefficients on (1) Equal ?) & 0.86 & & \\
F-Prob & 0.4214 & & \\
\hline
\end{tabular}

\subsection{Village Access to Local Wage Employment in Collective Enterprises}

\begin{tabular}{|c|c|c|c|}
\hline \multirow[b]{2}{*}{ Regressor } & \multicolumn{3}{|c|}{ Lagged Household Wealth Tercile } \\
\hline & High & Medium & Low \\
\hline $\begin{array}{l}\text { (1) } \Delta[\text { (Area of Land Managed By the } \\
\text { Household)*(Rainfall Shock)] }\end{array}$ & $\begin{array}{l}-0.0009 \\
(0.0004)\end{array}$ & $\begin{array}{l}-0.0005 \\
(0.0003)\end{array}$ & $\begin{array}{r}0.0000 \\
(0.0004)\end{array}$ \\
\hline $\begin{array}{l}\text { (2) }[\Delta \text { (Area of Land Managed By the } \\
\text { Household)*(Rainfall Shock) }]^{*} \text { VColl }_{t}\end{array}$ & $\begin{array}{c}0.0048 \\
(0.0018)\end{array}$ & $\begin{array}{c}0.0043 \\
(0.0020)\end{array}$ & $\begin{array}{c}0.0037 \\
(0.0028)\end{array}$ \\
\hline $\begin{array}{l}\text { F-Test (Coefficients on (1) Equal ?) } \\
\text { F-Prob }\end{array}$ & $\begin{array}{c}2.97 \\
0.0515\end{array}$ & & \\
\hline $\begin{array}{l}\text { F-Test (Coefficients on (1) Equal ?) } \\
\text { F-Prob }\end{array}$ & $\begin{array}{c}0.1 \\
0.9093\end{array}$ & & \\
\hline
\end{tabular}

Specifications 8.1-8.5 run the same specifications as in Table 7, but the entire sample is split. The only coefficients shown are those related to the idiosyncratic effect of the rainfall shock. 
Tables 8.4-8.5

\subsection{Village Access to Local Wage Employment in Private Enterprises}

\begin{tabular}{lccc} 
& \multicolumn{3}{c}{ Lagged Household Wealth Tercile } \\
Regressor & High & Medium & Low \\
\hline (1) $\Delta[($ Area of Land Managed By the & -0.0007 & -0.0006 & \multirow{2}{*}{0.0001} \\
Household)*(Rainfall Shock)] & $(0.0004)$ & $(0.0004)$ & $(0.0005)$ \\
& & & \\
(2) $[\Delta$ (Area of Land Managed By the & 0.0041 & 0.0077 & 0.0040 \\
Household)*(Rainfall Shock) ${ }^{*}$ VPriv & \\
\hline F-Test (Coefficients on (1) Equal ?) & $(0.0037)$ & $(0.0033)$ & $(0.0038)$ \\
F-Prob & 2.2 & & \\
F-Test (Coefficients on (1) Equal ?) & 0.1105 & & \\
F-Prob & 0.9 & & \\
\hline
\end{tabular}

\subsection{Village Access to Local Wage Employment}

\begin{tabular}{lccc} 
& \multicolumn{3}{c}{ Lagged Household Wealth Tercile } \\
Regressor & High & Medium & Low \\
\hline$\Delta[($ Area of Land Managed By the & -0.0012 & -0.0009 & -0.0002 \\
Household)*(Rainfall Shock) & $(0.0004)$ & $(0.0004)$ & $(0.0005)$ \\
{$[\Delta($ Area of Land Managed By the } & 0.0042 & 0.0046 & 0.0032 \\
Household)*(Rainfall Shock) $]^{*}$ VLoc & $(0.0015)$ & $(0.0016)$ & $(0.0020)$ \\
\hline F-Test (Coefficients on (1) Equal ?) & 2.45 & & \\
F-Prob & 0.0867 & & \\
F-Test (Coefficients on (1) Equal ?) & 0.27 & & \\
F-Prob & 0.7612 & & \\
\hline
\end{tabular}

Specifications 8.1-8.5 run the same specifications as in Table 7, but the entire sample is split. The only coefficients shown are those related to the idiosyncratic effect of the rainfall shock. 
Table 9

Village Access to Off-Farm Labor Markets and the Impact of Rainfall Shocks on Education Expenditures

Dependent Variable: $\Delta$ (Education Expenditures Per Dependent)

\begin{tabular}{|c|c|c|c|c|c|}
\hline Regressor & (1) & $(2)$ & $(3)$ & $(4)$ & (5) \\
\hline$\Delta$ Male Laborers & $\begin{array}{l}2.76 \\
(2.94)\end{array}$ & $\begin{array}{l}2.76 \\
(2.94)\end{array}$ & $\begin{array}{l}2.80 \\
(2.94)\end{array}$ & $\begin{array}{c}2.80 \\
(2.94)\end{array}$ & $\begin{array}{c}2.83 \\
(2.94)\end{array}$ \\
\hline$\Delta$ Female Laborers & $\begin{array}{l}4.52 \\
(2.65)\end{array}$ & $\begin{array}{l}4.53 \\
(2.65)\end{array}$ & $\begin{array}{l}4.48 \\
(2.65)\end{array}$ & $\begin{array}{l}4.51 \\
(2.65)\end{array}$ & $\begin{array}{l}4.47 \\
(2.65)\end{array}$ \\
\hline$\Delta$ Dependents & $\begin{array}{l}-27.81 \\
(1.93)\end{array}$ & $\begin{array}{l}-27.82 \\
(1.93)\end{array}$ & $\begin{array}{l}-27.79 \\
(1.93)\end{array}$ & $\begin{array}{l}-27.79 \\
(1.93)\end{array}$ & $\begin{array}{l}-27.78 \\
(1.93)\end{array}$ \\
\hline $\begin{array}{l}\Delta \text { Share of Labor with Elementary } \\
\text { Education }\end{array}$ & $\begin{array}{l}17.89 \\
(6.73)\end{array}$ & $\begin{array}{l}17.89 \\
(6.73)\end{array}$ & $\begin{array}{l}17.80 \\
(6.73)\end{array}$ & $\begin{array}{l}17.88 \\
(6.73)\end{array}$ & $\begin{array}{l}17.80 \\
(6.73)\end{array}$ \\
\hline $\begin{array}{l}\Delta \text { Share of Labor with Lower Middle } \\
\text { School Education }\end{array}$ & $\begin{array}{c}2.02 \\
(7.48)\end{array}$ & $\begin{array}{c}2.00 \\
(7.48)\end{array}$ & $\begin{array}{c}2.09 \\
(7.48)\end{array}$ & $\begin{array}{c}2.06 \\
(7.48)\end{array}$ & $\begin{array}{c}2.11 \\
(7.48)\end{array}$ \\
\hline $\begin{array}{l}\Delta \text { Share of Labor with Upper Middle } \\
\text { School Education }\end{array}$ & $\begin{array}{c}0.22 \\
(11.32)\end{array}$ & $\begin{array}{c}0.23 \\
(11.32)\end{array}$ & $\begin{array}{c}0.36 \\
(11.32)\end{array}$ & $\begin{array}{c}0.33 \\
(11.32)\end{array}$ & $\begin{array}{c}0.43 \\
(11.32)\end{array}$ \\
\hline$\Delta$ Share of Labor with Special Skill & $\begin{array}{l}13.13 \\
(7.84)\end{array}$ & $\begin{array}{l}13.15 \\
(7.84)\end{array}$ & $\begin{array}{l}12.90 \\
(7.84)\end{array}$ & $\begin{array}{l}13.07 \\
(7.84)\end{array}$ & $\begin{array}{l}12.87 \\
(7.84)\end{array}$ \\
\hline $\begin{array}{l}\Delta \text { Area of Land Managed By the } \\
\text { Household }\end{array}$ & $\begin{array}{l}2.50 \\
(0.74)\end{array}$ & $\begin{array}{l}2.50 \\
(0.74)\end{array}$ & $\begin{array}{l}2.48 \\
(0.74)\end{array}$ & $\begin{array}{c}2.50 \\
(0.74)\end{array}$ & $\begin{array}{l}2.48 \\
(0.74)\end{array}$ \\
\hline $\begin{array}{l}\Delta[(\text { Area of Land Managed By the } \\
\text { Household)*(Rainfall Shock)] }\end{array}$ & $\begin{array}{l}-0.30 \\
(0.16)\end{array}$ & $\begin{array}{l}-0.34 \\
(0.20)\end{array}$ & $\begin{array}{l}-0.50 \\
(0.19)\end{array}$ & $\begin{array}{l}-0.46 \\
(0.21)\end{array}$ & $\begin{array}{l}-0.60 \\
(0.21)\end{array}$ \\
\hline $\begin{array}{l}{[\Delta(\text { Area of Land Managed By the }} \\
\text { Household)*(Rainfall Shock) }]^{*} \text { VMig }\end{array}$ & & $\begin{array}{c}0.56 \\
(1.98)\end{array}$ & & & \\
\hline $\begin{array}{l}{[\Delta(\text { Area of Land Managed By the }} \\
\left.\text { Household })^{*}(\text { Rainfall Shock })\right]^{*} \text { VColl }\end{array}$ & & & $\begin{array}{c}1.80 \\
(1.01)\end{array}$ & & \\
\hline $\begin{array}{l}{[\Delta \text { (Area of Land Managed By the }} \\
\left.\text { Household })^{*}(\text { Rainfall Shock })\right]^{*} \text { VPriv }_{t}\end{array}$ & & & & $\begin{array}{c}2.19 \\
(1.89)\end{array}$ & \\
\hline $\begin{array}{l}{[\Delta(\text { Area of Land Managed By the }} \\
\text { Household })^{*}(\text { Rainfall Shock) }]^{*} \text { VLoc }\end{array}$ & & & & & $\begin{array}{c}1.63 \\
(0.82)\end{array}$ \\
\hline$R^{2}$ & 0.05 & 0.05 & 0.05 & 0.05 & 0.05 \\
\hline Observations & 21814 & 21814 & 21814 & 21814 & 21814 \\
\hline
\end{tabular}

Village*Year dummy variables are jointly statistically significant, but not shown. 